\title{
Synthesis of higher alcohols on copper catalysts supported on alkali-promoted basic oxides
}

\author{
Anne-Mette Hilmen, Mingting Xu, Marcelo J.L. Gines, Enrique Iglesia* \\ Department of Chemical Engineering, University of California at Berkeley, Berkeley, CA 94720, USA
}

Received 20 September 1997; received in revised form 13 January 1998; accepted 13 January 1998

\begin{abstract}
$\mathrm{K}-\mathrm{Cu}_{y} \mathrm{Mg}_{5} \mathrm{CeO}_{x}$ and $\mathrm{Cs}-\mathrm{Cu} / \mathrm{ZnO} / \mathrm{Al}_{2} \mathrm{O}_{3}$ are selective catalysts for the synthesis of alcohols from an $\mathrm{H}_{2} / \mathrm{CO}$ mixture at relatively low pressures and temperatures. $\mathrm{CO}_{2}$ produced in higher alcohol synthesis and water-gas shift (WGS) reactions reversibly inhibits the formation of methanol and higher alcohols by increasing oxygen coverages on $\mathrm{Cu}$ surfaces and by titrating basic sites required for aldol-type chain growth steps. Inhibition effects are weaker on catalysts with high $\mathrm{Cu}$-site densities. On these catalysts, the abundance of $\mathrm{Cu}$ sites allows reactants to reach methanol synthesis equilibrium and maintain a sufficient number of $\mathrm{Cu}$ surface atoms for bifunctional condensation steps, even in the presence of $\mathrm{CO}_{2}$. The addition of Pd to $\mathrm{K}-\mathrm{Cu}_{0.5} \mathrm{Mg}_{5} \mathrm{CeO}_{x}$ weakens $\mathrm{CO}_{2}$ inhibition effects, because Pd remains metallic and retains its hydrogenation activity during $\mathrm{CO}$ hydrogenation. Basic sites on $\mathrm{Mg}_{5} \mathrm{CeO}_{\mathrm{x}}$ are stronger than on $\mathrm{ZnO} / \mathrm{Al}_{2} \mathrm{O}_{3}$ and they are more efficiently covered by $\mathrm{CO}_{2}$ during alcohol synthesis. $\mathrm{K}$ and Cs block acid sites that form dimethylether and hydrocarbons. Alcohol addition studies show that chain growth occurs predominantly by aldol-type addition of methanol-derived $\mathrm{C}_{1}$ species to ethanol and higher alcohols, following the rules of base-catalyzed aldol condensations. The initial $\mathrm{C}-\mathrm{C}$ bond formation required for ethanol synthesis, however, proceeds directly from $\mathrm{CO}$, at least on $\mathrm{K}-\mathrm{Cu}_{y} \mathrm{Mg}_{5} \mathrm{CeO}_{x}$ catalysts. A detailed kinetic analysis shows that chain growth probabilities are very similar on $\mathrm{K}-\mathrm{Cu}_{y} \mathrm{Mg}_{5} \mathrm{CeO}_{x}$ and $\mathrm{Cs}-\mathrm{Cu} / \mathrm{ZnO} / \mathrm{Al}_{2} \mathrm{O}_{3}$ catalysts. The growth probabilities of $\mathrm{C}_{1}$ chains to ethanol and of $i s o-\mathrm{C}_{4}$ chains to higher alcohols are much lower than for other chain growth steps. (C) 1998 Elsevier Science B.V.
\end{abstract}

Keywords: Higher alcohols; Isobutanol; Methanol; Copper; Basic oxides; Potassium; Cesium

\section{Introduction}

The selective synthesis of methanol and isobutanol is attractive for the subsequent manufacture of methyltert-butyl-ether (MTBE) after isobutanol dehydration to form isobutene. An equimolar ratio of methanol to isobutanol would be preferred for MTBE synthesis.

\footnotetext{
*Corresponding Author. Fax: (510) 642-4778; e-mail: iglesia@cchem.berkeley.edu
}

Methanol and higher alcohols can also be used for direct blending with hydrocarbon fuels. Mixtures of higher alcohols and methanol are preferred over pure methanol because of their higher water tolerance, reduced fuel volatility and lower vapor lock tendency, and also because their volumetric heating values are higher than for pure methanol [1].

The addition of alkali to Cu-based methanol synthesis catalysts leads to the formation of higher alcohols from $\mathrm{H}_{2} / \mathrm{CO}$ mixtures [1,2]. Cs appears to be the best 
promoter for higher alcohol synthesis, but $\mathrm{Rb}$ and $\mathrm{K}$ also increase the selectivity to higher alcohols [3-5]. Potassium is often used because of its availability and low cost. The most studied catalysts for low-temperature higher alcohol synthesis are based on $\mathrm{Cu}$ and $\mathrm{ZnO}$, often with $\mathrm{Al}_{2} \mathrm{O}_{3}$ or $\mathrm{Cr}_{2} \mathrm{O}_{3}$ as structural promoters that increase the surface area and prevent sintering [3-25]. Other $\mathrm{Cu}$-based catalysts, such as $\mathrm{K}-\mathrm{Cu}_{x} \mathrm{Mg}_{y} \mathrm{CeO}_{z}$ [26,27], have recently been shown to catalyze the synthesis of isobutanol at low temperatures. $\mathrm{Li}-\mathrm{Pd} / \mathrm{ZrO}_{2}-\mathrm{MnO}_{2}-\mathrm{ZnO}$ catalysts show very high isobutanol synthesis productivity at high temperatures $(>673 \mathrm{~K})$ and pressures $(>10 \mathrm{MPa})$ [28].

The development of isobutanol synthesis catalysts that function at relatively low temperatures $(<623 \mathrm{~K})$ and pressures $(<10 \mathrm{MPa})$ can decrease process costs and allow the use of large-scale slurry bubble column reactors. These reactors are well-suited for highly exothermic reactions because of their excellent heat removal properties. At low temperatures, however, currently available catalysts show high methanol selectivities, because methanol equilibrium, which is closely approached during higher alcohol synthesis $[10,29]$, favors high methanol yields at low temperatures. Also, the kinetically-limited synthesis of higher alcohols becomes slower at low temperatures. As a result, the molar ratio of methanol to isobutanol is far from unity at low reaction temperatures.

The synthesis of methanol proceeds via reactions of $\mathrm{CO}_{2}$ when using $\mathrm{CO} / \mathrm{CO}_{2} / \mathrm{H}_{2}$ reactant mixtures and it is catalyzed by $\mathrm{Cu}$ surface atoms $[30,31]$. When $\mathrm{CO}_{2}-$ free feeds are used, the rate of methanol formation is not proportional to the $\mathrm{Cu}$ surface area [30]. In the absence of $\mathrm{CO}_{2}$, basic sites are required along with $\mathrm{Cu}$ sites in methanol synthesis from $\mathrm{H}_{2} / \mathrm{CO}$ mixtures [30]. Isobutanol synthesis requires the initial formation of methanol and higher linear alcohols and subsequent chain growth reactions leading to 2-methyl alcohols.

The formation of ethanol remains the least understood step in this reaction sequence. Recent results suggests that ethanol is formed directly from $\mathrm{CO}$ on $\mathrm{K}-\mathrm{Cu}_{0.5} \mathrm{Mg}_{5} \mathrm{CeO}_{x}$ catalysts [32], but via methanol condensation steps on $\mathrm{Cs}-\mathrm{Cu} / \mathrm{ZnO} / \mathrm{Al}_{2} \mathrm{O}_{3}$ [20,32]. Although methanol is not involved in the formation of ethanol on $\mathrm{K}-\mathrm{Cu}_{0.5} \mathrm{Mg}_{5} \mathrm{CeO}_{x}$, it acts as a $\mathrm{C}_{1}$ precursor in the synthesis of 1-propanol and 2-methyl-1propanol from ethanol [33,34]. 2-Methyl-branched alcohols are formed by aldol condensation reactions; our recent studies have shown that these reactions require both $\mathrm{Cu}$ and basic sites [34]. Condensation steps occur on basic sites, but $\mathrm{Cu}$ sites appear to be required in order to remove hydrogen from the surface and to increase the rate of initial $\mathrm{C}-\mathrm{H}$ bond activation steps. The addition of $\mathrm{C}_{1}$ species to isobutanol is slow because of steric effects and also because isobutanol lacks the two $\alpha$-hydrogens required for aldol condensation reactions.

Small amounts of $\mathrm{CO}_{2}(\sim 2 \%)$ promote methanol formation, but higher concentrations inhibit methanol synthesis $[4,17]$. The sensitivity to $\mathrm{CO}_{2}$ depends on catalyst composition. Vedage et al. [4] have shown that methanol synthesis rates on $\mathrm{Cu} / \mathrm{ZnO}$ increased when 2-6\% $\mathrm{CO}_{2}$ was added to $\mathrm{H}_{2} / \mathrm{CO}$ mixtures, but much smaller rate enhancements were observed when such catalysts were modified with Cs. Steady-state oxygen coverages on $\mathrm{Cu}$ surfaces during methanol synthesis depend on the relative rates of addition and removal of oxygen during $\mathrm{CO}$ hydrogenation reactions [35]. At high $\mathrm{CO}_{2}$ concentrations and in the presence of alkali, the rate of surface oxidation increases relative to reduction, leading to higher steady-state oxygen coverages and to a (reversible) decrease in the number of surface $\mathrm{Cu}$ metal atoms available for methanol synthesis steps. Similar trends have been reported for higher alcohol synthesis on alkali-modified methanol synthesis catalysts [9].

Our study focuses on catalysts consisting of $\mathrm{Cu}$ metal crystallites supported on basic oxides for the synthesis of methanol-isobutanol mixtures at low temperatures and pressures. This study includes studies of the effects of residence time, alloying, $\mathrm{Cu}$-site density and crystallite size, and $\mathrm{CO}_{2}$ and alcohol addition to $\mathrm{H}_{2}-\mathrm{CO}$ reactants on reactions rates and selectivities, designed to probe reaction pathways required for isobutanol synthesis. It also includes some structural characterization data for $\mathrm{K}-\mathrm{Cu}_{y} \mathrm{Mg}_{5}$ $\mathrm{CeO}_{x}$ and $\mathrm{Cs}-\mathrm{Cu} / \mathrm{ZnO} / \mathrm{Al}_{2} \mathrm{O}_{3}$ catalytic materials.

\section{Experimental}

\subsection{Catalyst preparation}

$\mathrm{CuMgCeO}_{x}$ samples were prepared by coprecipitation of mixed nitrate solutions with an aqueous solution of $\mathrm{KOH}(2 \mathrm{M})$ and $\mathrm{K}_{2} \mathrm{CO}_{3}(1 \mathrm{M})$ at $338 \mathrm{~K}$ at a 
constant $\mathrm{pH}$ of 9 in a well-stirred and thermostated container. The precipitate was filtered, washed thoroughly with $300-500 \mathrm{~cm}^{3}$ deionized water at $333 \mathrm{~K}$, and dried at $353 \mathrm{~K}$ overnight. Dried samples were calcined at $723 \mathrm{~K}$ for $4 \mathrm{~h}$ in order to form the corresponding mixed oxides. Residual potassium in all dried samples measured by atomic absorption spectroscopy (AAS) was $<0.1 \mathrm{wt} \%$ before alkali impregnation. $\mathrm{Cu} / \mathrm{ZnO} / \mathrm{Al}_{2} \mathrm{O}_{3}$ samples $(\mathrm{Cu} / \mathrm{Zn} / \mathrm{Al}$ molar ratio $=54.8 / 30.1 / 15.1$ ) were prepared following the same procedures as for $\mathrm{CuMgCeO}_{x}$, except that the solution $\mathrm{pH}$ was held at 7.0 during precipitation and the dried powders were calcined at $623 \mathrm{~K}$ for $4 \mathrm{~h}$ [36]. $\mathrm{K}$ and $\mathrm{Cs}$ were added by incipient wetness using $\mathrm{K}_{2} \mathrm{CO}_{3}(0.25 \mathrm{M})$ and $\mathrm{CH}_{3} \mathrm{COOCs}(0.25 \mathrm{M})$ aqueous solutions $\left(\mathrm{K}_{2} \mathrm{CO}_{3}\right.$, Fisher Scientific, A.C.S. certified; $\mathrm{CH}_{3} \mathrm{COOCs}$, Strem Chemicals, 99.9\%). The Pd-promoted catalyst was prepared by incipient wetness impregnation of $\mathrm{Cu}_{0.5} \mathrm{Mg}_{5} \mathrm{CeO}_{x}$ with an aqueous solution of $\mathrm{Pd}\left(\mathrm{NH}_{3}\right)_{2}\left(\mathrm{NO}_{2}\right)_{2}$, followed by air oxidation $(0.5 \mathrm{~K} / \mathrm{min}$ to $723 \mathrm{~K}, 4 \mathrm{~h})$ before impregnation with $\mathrm{K}$.

\subsection{Catalyst characterization}

Total surface areas were determined by $\mathrm{N}_{2}$ physisorption at $77 \mathrm{~K}$ using a continuous flow Quantasorb surface-area analyzer (Quantachrome) and the BET analysis method. Bulk catalyst compositions were measured by atomic absorption spectroscopy (AAS). Copper metal surface areas were measured by $\mathrm{N}_{2} \mathrm{O}$ (Matheson, ultrahigh purity) decomposition on pre-reduced samples at $363 \mathrm{~K}$. A chemisorption stoichiometry of $0.5: 1 \mathrm{O}: \mathrm{Cu}_{\mathrm{s}}$ was used in order to estimate $\mathrm{Cu}$ surface areas and dispersions [37,38].

The density of basic sites was measured by temperature-programmed desorption (TPD) and isotopic switch methods using $\mathrm{CO}_{2}$ as a probe molecule [39]. Temperature-programmed $\mathrm{CO}_{2}$ desorption (TPD) measurements consisted of pretreating the sample (50 mg) in flowing $\mathrm{He}\left(\sim 100 \mathrm{~cm}^{3} / \mathrm{min}\right)$ at $723 \mathrm{~K}$ for $0.3 \mathrm{~h}$, followed by reduction in $5 \% \mathrm{H}_{2} / \mathrm{He}$ at $623 \mathrm{~K}$ for $0.5 \mathrm{~h}$. The sample was then exposed to $\mathrm{CO}_{2}(\mathrm{Cam}-$ bridge Isotope Laboratories) for $0.15 \mathrm{~h}$ at room temperature, flushed with $\mathrm{He}$ in order to remove gas phase and weakly adsorbed $\mathrm{CO}_{2}$, and the temperature increased up to $723 \mathrm{~K}$ at a rate of $0.5 \mathrm{~K} / \mathrm{s}$. The desorption profile of $\mathrm{CO}_{2}$ was monitored continuously by mass spectrometry.
Exchangeable $\mathrm{CO}_{2}$ was measured by a ${ }^{13} \mathrm{CO}_{2} /$ ${ }^{12} \mathrm{CO}_{2}$ isotopic switch method. Pre-reduced samples were exposed to $0.1 \%{ }^{13} \mathrm{CO}_{2} / 0.1 \% \mathrm{Ar} / \mathrm{He}$ (Cambridge Isotope Laboratories) at $573 \mathrm{~K}$. After ${ }^{13} \mathrm{CO}_{2}$ reached a constant concentration in the effluent stream $(0.5 \mathrm{~h})$, the flow was switched to $0.1 \%{ }^{12} \mathrm{CO}_{2} / \mathrm{He}$ (Cambridge Isotope Laboratories). Mass spectrometric analysis of ${ }^{13} \mathrm{CO}_{2}$ and $\mathrm{Ar}$ concentrations as a function of time after the isotopic switch were used to follow the decay in the concentration of ${ }^{13} \mathrm{CO}_{2}$ as it was replaced on the surface by ${ }^{12} \mathrm{CO}_{2}$. This method and the required data analysis protocols have been described in detail elsewhere [34,39].

\subsection{High-pressure microreactor studies}

High-pressure isobutanol synthesis studies were performed in a $1.27 \mathrm{~cm}$ i.d. stainless steel fixed-bed reactor with an axisymmetric thermowell $(0.32 \mathrm{~cm}$ diameter). This reactor was held within a three-zone heated furnace in order to ensure uniform axial temperatures. The catalyst $(2 \mathrm{~g})$ was reduced in pure $\mathrm{H}_{2}$ (Matheson, 99.99\%) at 573-593 K and atmospheric pressure for $12 \mathrm{~h}$ before catalytic experiments were carried out at 4.5 MPa using synthesis gas mixtures $\left(\mathrm{H}_{2} / \mathrm{CO} / \mathrm{Ar}\right.$ 0.45/0.45/0.1 mol.; Matheson: $99.99 \%$ CO, $99.99 \%$ Ar). Metal carbonyls were removed from synthesis gas streams using activated carbon (SorbTech RL-13). $\mathrm{H}_{2}$ was purified by passing through a catalytic purifier (Matheson, Model 64-1008). Traces of water were removed from $\mathrm{H}_{2}$ and $\mathrm{H}_{2} / \mathrm{CO}$ using molecular sieves (Matheson, Model 452:4A).

Analysis of the reactor effluent was carried out at regular intervals using a Hewlett-Packard 5890 II Plus gas chromatograph with thermal-conductivity (TCD) and flame-ionization (FID) detectors. Products and reactants were separated using a 5\% phenylmethyl-silicone capillary column (HP-5, $50 \mathrm{~m}$, $0.32 \mathrm{~mm}$ diameter, $1.05 \mu \mathrm{m}$ film thickness) and a packed column (Porapak Q, $1.8 \mathrm{~m}$ length, $0.32 \mathrm{~cm}$ diameter). The concentration of $\mathrm{Ar}, \mathrm{N}_{2}, \mathrm{CO}$, and $\mathrm{CO}_{2}$ in the effluent from the packed column was measured using TCD. FID was used to measure the concentrations of all organic compounds eluting from the capillary column.

$\mathrm{CO}_{2} \quad\left(\mathrm{CO}_{2}: \mathrm{N}_{2}=1: 1\right.$; Altair, 99.998\% $\mathrm{CO}_{2}$, $99.998 \% \mathrm{~N}_{2}$ ) was added to the synthesis gas in order to examine the inhibiting effect of $\mathrm{CO}_{2}$ on methanol 
and isobutanol synthesis rates. $\mathrm{CO}_{2}$ was introduced together with an internal standard $\left(\mathrm{N}_{2}\right)$ in a $1: 1$ molar ratio. The gas mixture was passed through a molecular sieve (Matheson, Model 452:4A) in order to remove trace amounts of water.

1-Propanol or ethanol were added using a liquid syringe pump (ISCO $500 \mathrm{D}$ ). Liquid propanol and ethanol reactants were degassed by flowing $\mathrm{He}$ for $\sim 10 \mathrm{~h}$ before charging to the pump. After alcohol addition studies, the alcohol feed was stopped and the synthesis gas stream was kept flowing through the reactor in order to check recovery of activity and selectivity to the values measured before alcohol addition.

\section{Results and discussion}

\subsection{Characterization}

The characterization of $\mathrm{CuMgCeO}$-type catalysts has been discussed previously [34] and will be summarized only briefly here. X-Ray diffraction (XRD) patterns showed separate $\mathrm{MgO}$ and $\mathrm{CeO}_{x}$ phases after air treatment at $723 \mathrm{~K}$, suggesting that mixed $\mathrm{MgCeO}_{x}$ oxides did not form [34]. CuO crystallites were not detected by XRD, consistent with small $\mathrm{Cu}$ crystallites or with $\mathrm{Cu}$ atoms present in a solid solution with $\mathrm{CeO}_{2}$ [34]. Temperature-programmed reduction (TPR) studies showed that $\mathrm{CeO}_{2}$ promotes the reduction of copper, apparently by providing hydrogen dissociation sites [34]. $\mathrm{CeO}_{x}$ addition to $\mathrm{Cu}_{0.5} \mathrm{Mg}_{5} \mathrm{O}_{\mathrm{x}}$ increased both the total surface area and copper dispersion (Table 1), suggesting that it also acts as a structural promoter [34]. TPR studies showed that potassium inhibits the reduction of copper oxide during $\mathrm{H}_{2}$ treatment. This effect of alkali on copper is caused by inhibition of $\mathrm{H}_{2}$ activation and by the strengthening of $\mathrm{Cu}-\mathrm{O}$ bonds in $\mathrm{CuO}$ [34]. Copper dispersion decreased with increasing potassium loading (Table 1), because alkali species block surface $\mathrm{Cu}$ atoms and inhibit the reduction of $\mathrm{CuO}$, and also because potassium decreases the surface area of $\mathrm{Mg}_{5} \mathrm{CeO}_{x}$ supports.

\subsection{Methanol synthesis}

Methanol can be formed from synthesis gas via reaction (1). Methanol synthesis catalysts, however, also catalyze water-gas shift reactions (2). The stoichiometry of methanol synthesis from $\mathrm{CO}_{2}$ is described by reaction (3).

$$
\begin{aligned}
& \mathrm{CO}+2 \mathrm{H}_{2} \rightarrow \mathrm{CH}_{3} \mathrm{OH} \\
& \mathrm{CO}+\mathrm{H}_{2} \mathrm{O} \rightarrow \mathrm{CO}_{2}+\mathrm{H}_{2} \\
& \mathrm{CO}_{2}+3 \mathrm{H}_{2} \rightarrow \mathrm{CH}_{3} \mathrm{OH}+\mathrm{H}_{2} \mathrm{O}
\end{aligned}
$$

The $\mathrm{H}_{2} / \mathrm{CO}$ consumption ratio for methanol produced from $\mathrm{CO}$ is $2: 1$. Based on the stoichiometry of higher alcohol synthesis (reaction (4)), the $\mathrm{H}_{2} / \mathrm{CO}$ consumption ratio for this reaction should also be $2: 1$. However, simultaneous WGS reactions modify this ratio, as illustrated by the combination of reactions (2) and (4) resulting in reaction (5).

Table 1

Composition, surface area, and basic site density of mixed metal oxides.

\begin{tabular}{lllllll}
\hline Sample & $\begin{array}{l}\mathrm{Cu} \text { loading } \\
(\mathrm{wt} \%)\end{array}$ & $\begin{array}{l}\mathrm{K}(\mathrm{Cs})^{\mathrm{a}} \\
\text { content } \\
(\mathrm{wt} \%)\end{array}$ & $\begin{array}{l}\mathrm{BET} \\
\text { surface } \\
\text { area }\left(\mathrm{m}^{2} / \mathrm{g}\right)\end{array}$ & $\begin{array}{l}\mathrm{Cu}^{\mathrm{b}} \\
\text { dispersion }\end{array}$ & $\begin{array}{l}\text { Exchangeable } \\
\mathrm{CO}_{2}(\text { at } 573 \mathrm{~K}) \\
\left(\mu \mathrm{mol} / \mathrm{m}^{2}\right)\end{array}$ & $\begin{array}{l}\mathrm{CO}{ }_{2} \text { desorbed } \\
\text { during TPD below } \\
573 \mathrm{~K}\left[\left(\mathrm{~mol} / \mathrm{m}^{2}\right]\right.\end{array}$ \\
\hline $\mathrm{Cu}_{0.5} \mathrm{Mg}_{5} \mathrm{O}_{x}$ & 13.2 & 0.2 & 118 & 0.06 & - & - \\
$\mathrm{Cu}_{0.5} \mathrm{Mg}_{5} \mathrm{CeO}_{x}$ & 7.7 & 0.1 & 167 & 0.23 & 1.2 & 0.62 \\
$\mathrm{Cu}_{0.5} \mathrm{Mg}_{5} \mathrm{CeO}_{x}$ & 7.7 & 1.0 & 147 & 0.14 & 2.3 & 0.64 \\
$\mathrm{Cu}_{0.5} \mathrm{Mg}_{5} \mathrm{CeO}_{x}$ & 7.7 & 3.5 & 62 & 0.06 & 5.2 & 0.65 \\
$\mathrm{Cu}_{7.5} \mathrm{Mg}_{5} \mathrm{CeO}_{x}$ & 49 & 1.2 & 92 & 0.05 & 3.3 & 0.91 \\
$\mathrm{Cu} / \mathrm{ZnO} / \mathrm{Al}_{2} \mathrm{O}_{3}$ & 44 & $(1.2)$ & 74 & 0.045 & 0.13 & 0.62 \\
$\mathrm{Cu} / \mathrm{ZnO} / \mathrm{Al}_{2} \mathrm{O}_{3}$ & 44 & $(2.9)$ & 62 & 0.05 & 1.1 & 0.72 \\
\hline
\end{tabular}

\footnotetext{
${ }^{a}$ Bulk composition measured by atomic absorption. Values in parenthesis are for catalysts promoted with $\mathrm{Cs}$ instead of $\mathrm{K}$.

${ }^{b}$ Dispersion calculated from the ratio of surface $\mathrm{Cu}$ (determined by $\mathrm{N}_{2} \mathrm{O}$ decomposition at $363 \mathrm{~K}[37,38]$ ) to the total number of $\mathrm{Cu}$ atoms in the catalyst.
} 


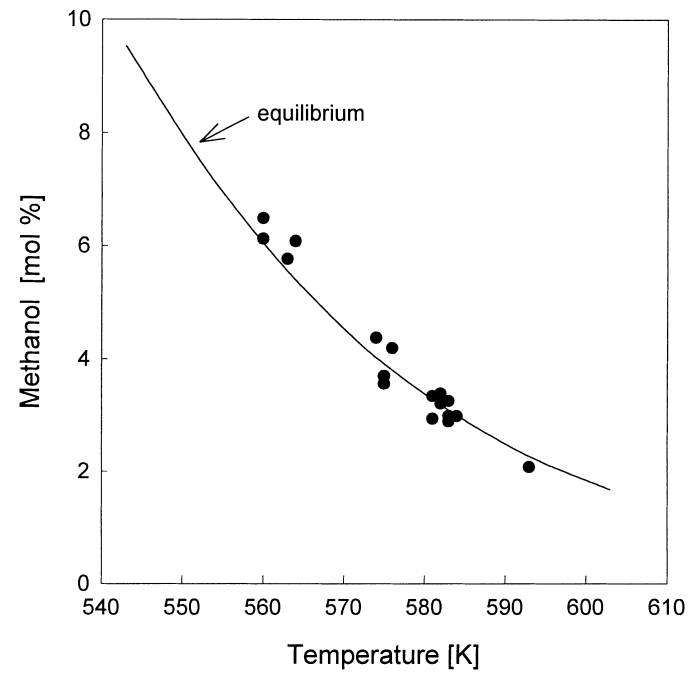

Fig. 1. Methanol mole fraction as a function of reaction temperature for $\mathrm{Cs}-\mathrm{Cu} / \mathrm{ZnO} / \mathrm{Al}_{2} \mathrm{O}_{3}$ and $\mathrm{K}-\mathrm{Cu}_{y} \mathrm{Mg}_{5} \mathrm{CeO}_{x}$ (4.5 MPa, $1500-6000 \mathrm{~cm}^{3} / \mathrm{g} / \mathrm{h}, \mathrm{H}_{2} / \mathrm{CO}=1$. ( $(-)$ ), equilibrium methanol mole fraction).

$$
\begin{aligned}
& n \mathrm{CO}+2 n \mathrm{H}_{2} \rightarrow \mathrm{C}_{n} \mathrm{H}_{2 n+1} \mathrm{OH}+(n-1) \mathrm{H}_{2} \mathrm{O} \\
& (2 n-1) \mathrm{CO}+(n+1) \mathrm{H}_{2} \\
& \quad \rightarrow \mathrm{C}_{n} \mathrm{H}_{2 n+1} \mathrm{OH}+(n-1) \mathrm{CO}_{2}
\end{aligned}
$$

Thus, the $\mathrm{H}_{2} / \mathrm{CO}$ usage ratio tends to decrease with increasing alcohol chain length, because the larger number of water molecules formed is subsequently converted to $\mathrm{CO}_{2}$ and $\mathrm{H}_{2}$ in reaction (2).

Fig. 1 shows how the measured mole fraction of methanol in the effluent stream varies with temperature for $\mathrm{CO}_{2}$-free synthesis gas feeds. Calculated equilibrium methanol mole fractions, when methanol is produced by reaction (1) are also plotted in Fig. 1. The equilibrium mole fraction was calculated using temperature and pressure correlations for the equilibrium constant reported by Klier et al. [17] for nonideal gas mixtures. The excellent agreement between measured and thermodynamic methanol concentrations shows that methanol synthesis from $\mathrm{H}_{2}-\mathrm{CO}$ mixtures is at thermodynamic equilibrium at the reactor exit for the conditions of this study. As a result, the effect of changing process variables such as temperature, pressure, feed composition on methanol synthesis rates can be predicted accurately from thermodynamic data. When methanol yields are limited by equilibrium, synthesis rates become propor- tional to space velocity, because $\mathrm{CO}$ conversions to methanol remain constant with increasing bed-residence time, as illustrated for two catalysts in Fig. 2. The formation of higher alcohols is favored by higher temperatures and low space velocities. However, these conditions also favor the rapid equilibration of methanol synthesis reactions.

Methanol synthesis catalysts also catalyze WGS reactions and the latter reaction is likely to also approach equilibrium during higher alcohol synthesis. WGS reactions convert the water formed in the synthesis of higher alcohols, hydrocarbons, and dimethylether (DME), to $\mathrm{CO}_{2}$ and $\mathrm{H}_{2}$, while consuming $\mathrm{CO}$, because thermodynamics favors the formation of $\mathrm{CO}_{2}\left(\mathrm{~K}_{\mathrm{eq}}=30\right)$ at our reaction conditions. Water can inhibit higher alcohol synthesis [40]; therefore its conversion to $\mathrm{CO}_{2}$ may be desirable. Rapid WGS equilibration, however, makes it difficult to independently determine the inhibitory effect of $\mathrm{CO}_{2}$ and $\mathrm{H}_{2} \mathrm{O}$ on alcohol synthesis reactions, because the addition of $\mathrm{CO}_{2}$ leads to an increase in both $\mathrm{H}_{2} \mathrm{O}$ and $\mathrm{CO}_{2}$ concentrations.

\subsection{Bed-residence time effects}

The effects of space velocity (bed-residence time) on alcohol synthesis rates and selectivities are shown in Fig. 2 for $1.2 \mathrm{wt} \% \mathrm{Cs}-\mathrm{Cu} / \mathrm{ZnO} / \mathrm{Al} 2 \mathrm{O} 3$ and $1.0 \mathrm{wt} \%$ $\mathrm{K}-\mathrm{Cu}_{0.5} \mathrm{Mg}_{5} \mathrm{CeO}_{x}$ catalysts (data in Fig. $2 \mathrm{~b}$ were taken from Ref. [34]). CO conversions should increase linearly with increasing bed-residence time at the low $\mathrm{CO}$ conversions of our study, unless the predominant methanol synthesis steps approach thermodynamic equilibrium. The observed decrease in the slope for the CO conversion curve with increasing bed-residence time in Fig. 2 reflects mainly the rapid approach to methanol synthesis equilibrium, as discussed above. It may also be influenced by an inhibition effect of $\mathrm{CO}_{2}$ and $\mathrm{H}_{2} \mathrm{O}$ on methanol synthesis, which becomes stronger as $\mathrm{CO}_{2}$ and $\mathrm{H}_{2} \mathrm{O}$ concentrations increase with increasing $\mathrm{CO}$ conversion. Isobutanol and higher alcohols form in secondary chain growth reactions, such as methanol carbonylation and aldol coupling reactions; therefore, their concentrations increase with increasing bed residence. $\mathrm{C}_{2}-\mathrm{C}_{3}$ alcohols are intermediate products that undergo further chain growth. As a result, their selectivity reaches a maximum value at intermediate residence times. 

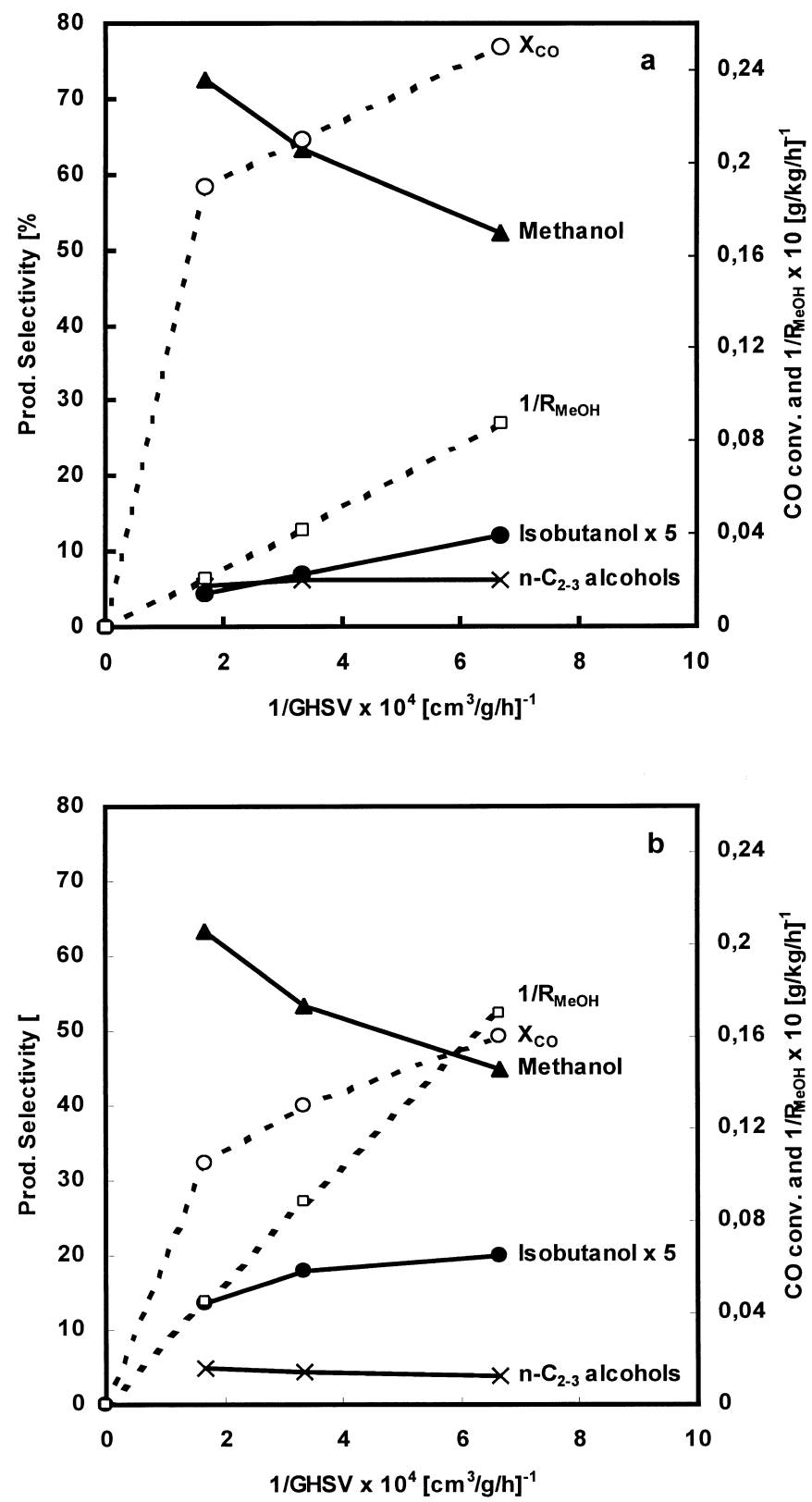

Fig. 2. $\mathrm{CO}$ conversion and product selectivities vs. space velocity on: a) $1.2 \mathrm{wt} \% \mathrm{Cs}-\mathrm{Cu} / \mathrm{ZnO} / \mathrm{Al}_{2} \mathrm{O}_{3}(563 \mathrm{~K})$; b) $1 \mathrm{wt} \% \mathrm{~K}-\mathrm{Cu}{ }_{0.5} \mathrm{Mg}{ }_{5} \mathrm{CeO}$. $(583 \mathrm{~K}),\left(4.5 \mathrm{MPa}, \mathrm{CO} / \mathrm{H}_{2}=1\right.$, product selectivities are on $\mathrm{CO}_{2}$-free basis).

Isobutanol is a kinetic end-product of aldol condensation chain growth processes, because it lacks the two $\alpha$-hydrogens required for facile chain growth via aldol condensation pathways. Therefore, isobutanol selectivity increases monotonically with increasing residence time. This increase, however, is less marked on $\mathrm{K}-\mathrm{Cu}_{0.5} \mathrm{Mg}_{5} \mathrm{CeO}_{x}$ than on $\mathrm{Cs}-\mathrm{Cu} / \mathrm{ZnO} / \mathrm{Al}_{2} \mathrm{O}_{3}$, because chain growth reactions are inhibited by $\mathrm{CO}_{2}$ reaction products more strongly on $\mathrm{K}-\mathrm{Cu}_{0.5} \mathrm{Mg}_{5-}$ $\mathrm{CeO}_{x}$ than on $\mathrm{Cs}-\mathrm{Cu} / \mathrm{ZnO} / \mathrm{Al}_{2} \mathrm{O}_{3}$. These effects are 
discussed in more detail below. $\mathrm{CO}_{2}$ appears to inhibit aldol-type coupling reactions during isobutanol synthesis on K-promoted $\mathrm{Cu}_{0.5} \mathrm{Mg}_{5} \mathrm{CeO}_{x}$ catalysts. Weaker basic sites on $\mathrm{Cs}-\mathrm{Cu} / \mathrm{ZnO} / \mathrm{Al}_{2} \mathrm{O}_{3}$ [34] appear to be less sensitive to $\mathrm{CO}_{2}$ poisoning; as a result, isobutanol selectivities reach higher values than on $\mathrm{K}-\mathrm{Cu}_{0.5} \mathrm{Mg}_{5}$ $\mathrm{CeO}_{x}$ as bed-residence time and $\mathrm{CO}$ conversion increase (Fig. 2(a) and (b)).

\section{4. $\mathrm{CO}_{2}$-addition to $\mathrm{H}_{2}$ - $\mathrm{CO}$ reactant mixtures}

The presence of $\mathrm{CO}_{2}$ in modest concentrations (1$2 \% \mathrm{~mol}$ ) increases methanol synthesis rates on typical methanol synthesis catalysts (e.g. $\mathrm{Cu} / \mathrm{ZnO} / \mathrm{Al}_{2} \mathrm{O}_{3}$ ) [17]. High $\mathrm{CO}_{2}$ concentrations $(>10 \% \mathrm{~mol})$ lead to surface oxidation and inhibit methanol synthesis on these catalysts [17]. Cs-modified methanol synthesis catalysts reach maximum rates at very low $\mathrm{CO}_{2}$ concentrations $(\sim 2 \% \mathrm{~mol})$ [3]. The relative rates of oxidation and reduction of $\mathrm{Cu}$ surface atoms determine the steady-state coverage of oxygen reaction intermediates during methanol synthesis. High concentrations of an oxidant, such as $\mathrm{CO}_{2}$ or $\mathrm{H}_{2} \mathrm{O}$, will increase the rate of oxidation relative to reduction and lead to higher steady-state oxygen coverages and to fewer $\mathrm{Cu}$ surface atoms available for methanol synthesis. These $\mathrm{Cu}$ surface metal atoms catalyze methanol synthesis reactions of $\mathrm{CO} / \mathrm{CO}_{2} / \mathrm{H}_{2}$ mixtures [30,31].

The details of $\mathrm{CO}_{2}$ inhibition effects on methanol and isobutanol synthesis were examined by adding $\mathrm{CO}_{2}$ to the $\mathrm{H}_{2} / \mathrm{CO}$ reactants. As already mentioned, the effect of $\mathrm{CO}_{2}$ cannot be separated from the effect of $\mathrm{H}_{2} \mathrm{O}$, because of the rapid equilibration of WGS reactions. $\mathrm{CO}_{2}$ addition results are shown in Fig. 3 as the reciprocal of the methanol, ethanol, 1-propanol, and isobutanol synthesis rates vs. $\mathrm{CO}_{2}$ concentration (data in Fig. 3(a) and (d) were taken from Ref. [34]). Typical Langmuir-Hinshelwood rate expressions (Eq. (6)) would lead to straight lines when data are plotted in this form, in agreement with the experimental data in Fig. 3.

$r=r_{0} /\left(1+K P_{\mathrm{CO} 2}\right)$

Methanol synthesis rates on catalysts with high $\mathrm{Cu}$ contents decreased only slightly as $\mathrm{CO}_{2}$ concentrations increased. Methanol synthesis rates on catalysts with lower $\mathrm{Cu}$ contents $\left(1.0 \mathrm{wt} \% \mathrm{~K}-\mathrm{Cu}_{0.5} \mathrm{Mg}_{5} \mathrm{CeO}_{x}\right)$ were more strongly inhibited by $\mathrm{CO}_{2}$. These results are consistent with the more complete approach to methanol synthesis equilibrium on catalysts with higher $\mathrm{Cu}$ surface densities. Catalysts containing a higher density of $\mathrm{Cu}$ surface sites (e.g. $1.0 \mathrm{wt} \% \mathrm{~K}-$ $\mathrm{Cu}_{7.5} \mathrm{Mg}_{5} \mathrm{CeO}_{x}$ and $\left.2.9 \mathrm{wt} \% \mathrm{Cs}-\mathrm{Cu} / \mathrm{ZnO} / \mathrm{Al}_{2} \mathrm{O}_{3}\right)$ can maintain equilibrium methanol concentrations even after a significant fraction of such sites are covered with oxygen adatoms during steady-state catalysis; therefore, the effect of $\mathrm{CO}_{2}$ on methanol productivity is observed only at higher $\mathrm{CO}_{2}$ concentrations. Equilibrium methanol concentrations vary slightly with $\mathrm{CO}_{2}$ concentration [29]. This may account for the slight decrease in methanol yield observed even on catalysts with high $\mathrm{Cu}$ content. Catalysts containing fewer $\mathrm{Cu}$ sites (e.g. $1.0 \mathrm{wt} \% \quad \mathrm{~K}-\mathrm{Cu}_{0.5} \mathrm{Mg}_{5} \mathrm{CeO}_{x}$ ) become unable to maintain methanol synthesis equilibrium conversions at lower $\mathrm{CO}_{2}$ concentrations than catalysts with higher density of $\mathrm{Cu}$ sites.

The effects of $\mathrm{CO}_{2}$ have not been as thoroughly studied in higher alcohol synthesis as in methanol synthesis. Tronconi et al. [40] observed decreased higher alcohol yields on $\mathrm{K}-\mathrm{ZnCrO}_{x}$ at $673 \mathrm{~K}$ when $\mathrm{CO}_{2}(3-6 \%)$ was added to the $\mathrm{H}_{2} / \mathrm{CO}$ feed. These authors proposed that water, formed from $\mathrm{CO}_{2}$ in reverse WGS reactions, titrated alcohol synthesis sites. Elliot [13] showed that synthesis rates for higher alcohols on $\mathrm{Cu} / \mathrm{ZnO}$ were increased by the addition of small amounts of $\mathrm{CO}_{2}(6 \%)$. Calverley and Smith [9] observed that higher alcohol synthesis rates at $558 \mathrm{~K}$ reach a maximum at intermediate $\mathrm{CO}_{2}$ concentrations $\left(\sim 4 \% \mathrm{CO}_{2}\right)$ on $\mathrm{Cu} / \mathrm{ZnO} / \mathrm{Cr}_{2} \mathrm{O}_{3}\left(0-0.5 \mathrm{wt} \% \mathrm{~K}_{2} \mathrm{CO}_{3}\right)$. They also reported that $\mathrm{CO}_{2}$ inhibition effects became stronger with increasing alkali at concentrations corresponding to $0.5-4.0 \mathrm{wt} \% \mathrm{~K}_{2} \mathrm{CO}_{3}$.

Fig. 3(b)-(d) show reciprocal ethanol, 1-propanol, and isobutanol synthesis rates as functions of the average $\mathrm{CO}_{2}$ partial pressure within the catalyst bed. The synthesis of higher alcohol synthesis on catalysts with low $\mathrm{Cu}$ content $\left(\mathrm{Cu}_{0.5} \mathrm{Mg}_{5} \mathrm{CeO}_{x}\right)$ was inhibited more strongly by $\mathrm{CO}_{2}$ than on catalysts with higher $\mathrm{Cu}$ content. This may reflect a slight decrease in methanol concentrations with increasing $\mathrm{CO}_{2}$ concentration (observed only on low-Cu content catalysts) and the reversible titration of both $\mathrm{Cu}$ and basic sites required for isobutanol synthesis. Although methanol appears not to be involved in the initial formation of ethanol on $\mathrm{K}-\mathrm{Cu}_{0.5} \mathrm{Mg}_{5} \mathrm{CeO}_{x}$ [32], it acts as a $\mathrm{C}_{1}$ precursor in the synthesis of 1-propanol and isobuta- 

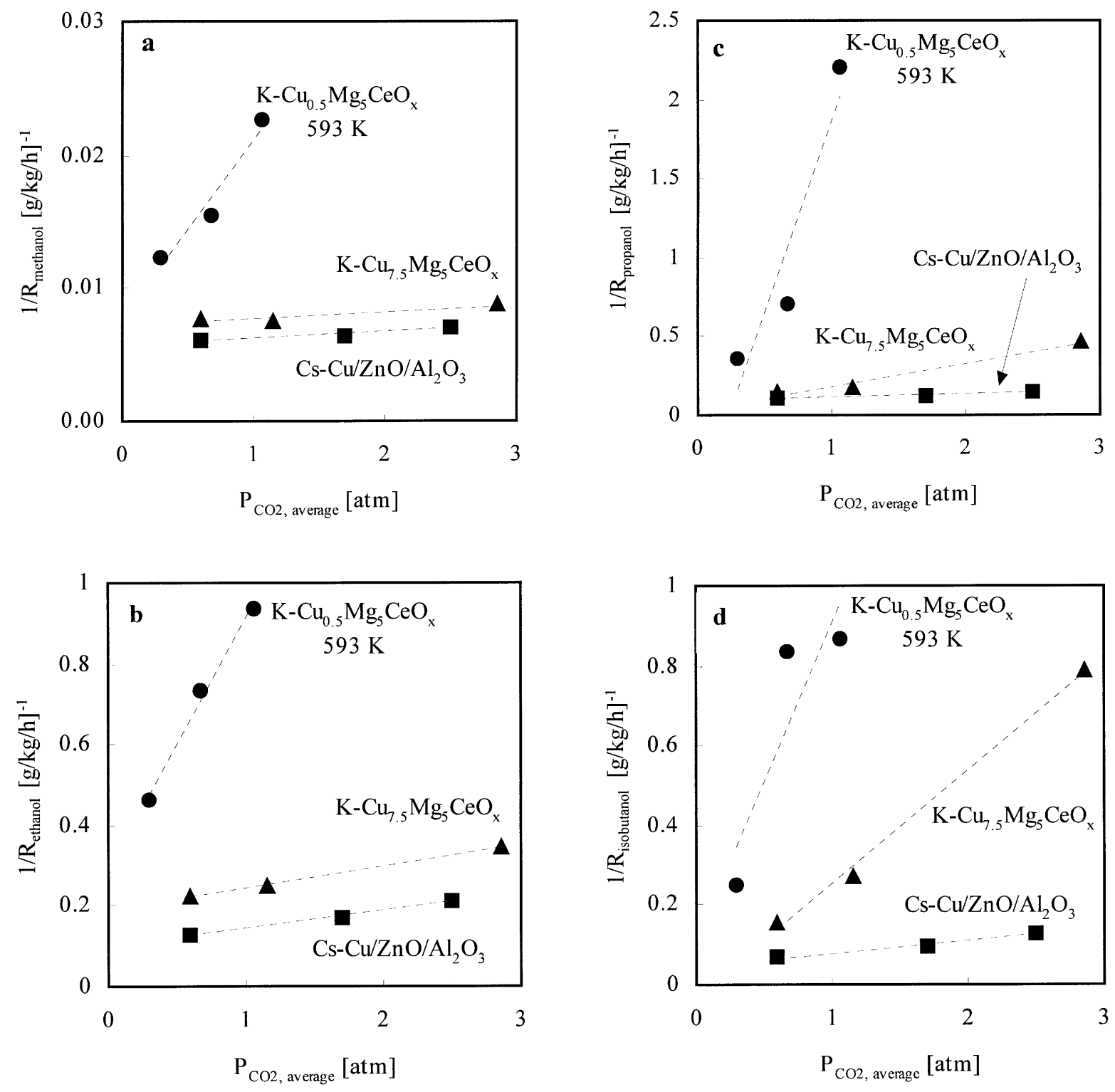

Fig. 3. Reciprocal methanol (a), ethanol (b), propanol (c) and isobutanol (d) productivity vs. average $\mathrm{CO}_{2}$ partial pressure on 1 wt. \% $\mathrm{K}$ $\mathrm{Cu}_{0.5} \mathrm{Mg}_{5} \mathrm{CeO}_{\mathrm{x}}, 2.9$ wt. \% Cs-Cu/ZnO$/ \mathrm{Al}_{2} \mathrm{O}_{3}$ and 0.9 wt. \% $\mathrm{K}-\mathrm{Cu}_{7.5} \mathrm{Mg}_{5} \mathrm{CeO}_{\mathrm{x}}$. [583 K, $\left.4.5 \mathrm{MPa}, 3000 \mathrm{~cm} / \mathrm{g} / \mathrm{h}, \mathrm{H}_{2} / \mathrm{CO}=1\right]$.

nol from ethanol. Aldol-type coupling reactions of alcohols require both $\mathrm{Cu}$ and basic sites [33]. Therefore, any blocking of surface $\mathrm{Cu}$ atoms by oxygen can also lead to a decrease in the rate of isobutanol synthesis, even when such blocking does not influence the rate of quasi-equilibrated methanol synthesis steps.
$\mathrm{CO}_{2}$ inhibition of isobutanol synthesis steps can also reflect the reversible titration of basic sites on oxide surfaces by acidic molecules, such as $\mathrm{CO}_{2}$. The inhibiting effect of $\mathrm{CO}_{2}$ on isobutanol synthesis rates is greater on $0.9 \mathrm{wt} \% \mathrm{~K}-\mathrm{Cu}_{7.5} \mathrm{Mg}_{5} \mathrm{CeO}_{x}$ than on $2.9 \mathrm{wt} \% \mathrm{Cs}-\mathrm{Cu} / \mathrm{ZnO} / \mathrm{Al}_{2} \mathrm{O}_{3}$, possibly because of the stronger basicity of the former (inferred from $\mathrm{CO}_{2}$ 
isotopic exchange and desorption rates [34]). On catalysts with low $\mathrm{Cu}$ content, chain growth reactions appear to be limited by the availability of minority $\mathrm{Cu}$ sites and, thus, reversible oxidation of surface $\mathrm{Cu}$ atoms by $\mathrm{CO}_{2}$ decreases chain growth rates. At higher $\mathrm{Cu}$ contents, chain growth rates become limited by steps occurring on basic sites, which are blocked by $\mathrm{CO}_{2}$ most effectively on the stronger basic sites available on the modified $\mathrm{MgO}$ materials. Basic sites on $0.9 \mathrm{wt} \% \mathrm{Cu}-\mathrm{Mg}_{7.5} \mathrm{Mg}_{5} \mathrm{CeO}_{x}$ appear to be more sensitive to $\mathrm{CO}_{2}$ than corresponding basic sites on $2.9 \mathrm{wt} \% \mathrm{Cs}-\mathrm{Cu} / \mathrm{ZnO} / \mathrm{Al}_{2} \mathrm{O}_{3}$, as previously shown from the faster $\mathrm{CO}_{2}$ isotopic exchange rates on the latter [34].

\subsection{Effect of Pd on $\mathrm{K}-\mathrm{Cu}_{0.5} \mathrm{Mg}_{5} \mathrm{CeO} \mathrm{O}_{x}$ catalysts}

Isobutanol synthesis steps on catalysts with low $\mathrm{Cu}$ content appears to be limited by the hydrogenation/ dehydrogenation function on these catalysts, especially at high $\mathrm{CO}_{2}$ concentrations as $\mathrm{Cu}$ surfaces become increasingly covered with oxygen atoms. $\mathrm{Pd}$ metal is an excellent hydrogenation/dehydrogenation catalyst and its presence in small amounts may provide hydrogenation sites even at high $\mathrm{CO}_{2}$ concentrations. Metal-oxygen bonds are weaker on $\mathrm{PdO}$ than on $\mathrm{CuO}$, and, thus, $\mathrm{Pd}$ metal is less likely to oxidize than $\mathrm{Cu}-$ metal $(\Delta G \approx-170$ and $-100 \mathrm{~kJ} / \mathrm{mol}$, respectively [41]). Pd has been used as catalyst for the synthesis of higher alcohols [28], but at much higher temperatures and pressures than those in this study.
Table 2 shows the effect of adding small amounts of $\mathrm{Pd}(0.25 \%$ wt. $\mathrm{Pd} ; \mathrm{Pd} / \mathrm{Cu}=0.02$ at. $)$ to $1 \mathrm{wt} \% \mathrm{~K}-$ $\mathrm{Cu}_{0.5} \mathrm{Mg}_{5} \mathrm{CeO}_{x}$. $\mathrm{CO}$ conversions are similar on both 1 wt. $\% \mathrm{~K}^{-} \mathrm{Cu}_{0.5} \mathrm{Mg}_{5} \mathrm{CeO}_{x}$ and $1 \mathrm{wt} \% \mathrm{~K}-0.25 \mathrm{wt} \%$ $\mathrm{Pd}-\mathrm{Cu}_{0.5} \mathrm{Mg}_{5} \mathrm{CeO}_{x}$ catalysts at all space velocities. Methanol synthesis rates are similar because methanol synthesis is near equilibrium on both catalysts.

Isobutanol synthesis rates are similar on the two catalysts only at high space velocities. Thus, Pd seems to have only a minor effect on the behavior of $1 \mathrm{wt} \%$ $\mathrm{K}-\mathrm{Cu}_{0.5} \mathrm{Mg}_{5} \mathrm{CeO}_{x}$, at low $\mathrm{CO}_{2}$ concentrations. At lower space velocities, however, the Pd-promoted catalyst shows higher isobutanol synthesis selectivity and rates, suggesting that $\mathrm{Pd}$ weakens the inhibitory effects of $\mathrm{CO}_{2}$. Pd crystallites appear to retain their hydrogenation activity as $\mathrm{CO}_{2}$ concentrations increase and continue to provide hydrogen activation sites required for bifunctional alcohol coupling reactions at significantly higher $\mathrm{CO}_{2}$ concentrations than on Pdfree catalysts. A horizontal line in Fig. 4 is expected for a differential reactor in the absence of product inhibition. The addition of $\mathrm{Pd}$ to the $\mathrm{K}-\mathrm{Cu}_{0.5} \mathrm{Mg}_{5} \mathrm{CeO}_{x}$ leads to a nearly horizontal line in Fig. 4.

\section{6. $\mathrm{Cu}$ concentration effects on methanol and isobutanol synthesis rates}

As shown previously, alcohol synthesis on catalysts with higher $\mathrm{Cu}$ concentrations is more weakly inhibited by $\mathrm{CO}_{2}$ than on catalysts with lower $\mathrm{Cu}$ contents. Therefore, high $\mathrm{Cu}$ concentrations could lead to higher

Table 2

Productivities and selectivities on $0.25 \mathrm{wt} \% \mathrm{Pd}-\mathrm{Cu}_{0.5} \mathrm{Mg}_{5} \mathrm{CeO}_{x}$ and $\mathrm{Cu}_{0.5} \mathrm{Mg}_{5} \mathrm{CeO}_{x}\left(583 \mathrm{~K}, 4.5 \mathrm{MPa}, \mathrm{H}_{2} / \mathrm{CO}=1\right)$

\begin{tabular}{|c|c|c|c|c|c|c|}
\hline \multirow{2}{*}{$\begin{array}{l}\text { Catalyst } \\
\text { Gas hourly space velocity }\left(\mathrm{cm}^{3} / \mathrm{g} / \mathrm{h}\right)\end{array}$} & \multicolumn{3}{|c|}{$(1 \mathrm{wt} \% \mathrm{~K}) 0.25 \mathrm{wt} \% \mathrm{Pd} \mathrm{Cu}_{0.5} \mathrm{Mg}_{5} \mathrm{CeO}_{x}$} & \multicolumn{3}{|c|}{$(1 \mathrm{wt} \% \mathrm{~K}) \mathrm{Cu}_{0.5} \mathrm{Mg}_{5} \mathrm{CeO}_{x}$} \\
\hline & 6000 & 3000 & 1500 & 6000 & 3000 & 1500 \\
\hline $\mathrm{CO}$ conversion $(\%)$ & 10.6 & 13.1 & 15.8 & 9.9 & 11.8 & 14.7 \\
\hline $\mathrm{CO}$ conversion rate (mmol CO conv./g/h) & 11.7 & 7.2 & 4.4 & 10.9 & 6.5 & 4.0 \\
\hline Methanol synthesis rate $(\mathrm{g} / \mathrm{kg} / \mathrm{h})$ & 236.2 & 130.4 & 64.5 & 227.8 & 122.2 & 65.0 \\
\hline Isobutanol synthesis rate $(\mathrm{g} / \mathrm{kg} / \mathrm{h})$ & 7.8 & 6.9 & 5.3 & 7.5 & 5.2 & 3.7 \\
\hline $\mathrm{CO}_{2}$-selectivity $[\% \mathrm{C}]$ & 19.2 & 22.8 & 28.1 & 15.6 & 18.1 & 23.4 \\
\hline \multicolumn{7}{|l|}{ Carbon selectivities (\% $\mathrm{C} ; \mathrm{CO}_{2}$-free) } \\
\hline Methanol & 74.3 & 68.4 & 59.3 & 75.2 & 71.1 & 63.1 \\
\hline Ethanol & 3.6 & 3.0 & 2.6 & 2.6 & 2.2 & 1.8 \\
\hline 1-Propanol & 3.7 & 4.1 & 4.1 & 3.6 & 3.3 & 3.0 \\
\hline Isobutanol & 4.3 & 6.2 & 8.4 & 4.3 & 5.1 & 6.2 \\
\hline Dimethylether & 1.0 & 1.2 & 1.6 & 4.0 & 4.5 & 6.8 \\
\hline Methyl acetate & 0.7 & 0.9 & 1.3 & 1.1 & 1.0 & 1.2 \\
\hline Paraffins selectivity & 6.3 & 8.7 & 13.3 & 4.7 & 6.5 & 9.9 \\
\hline
\end{tabular}




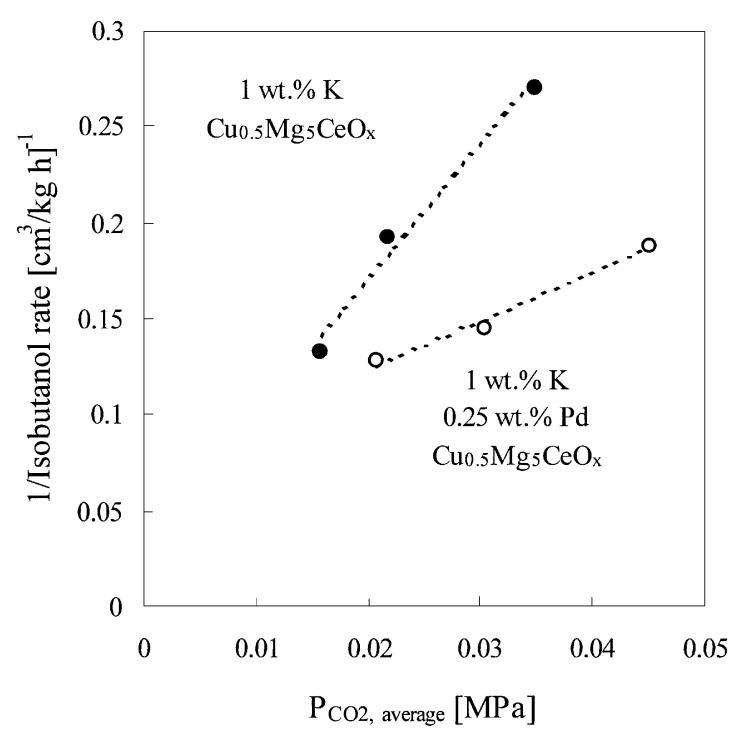

Fig. 4. Reciprocal isobutanol synthesis rate as a function of average $\mathrm{CO}_{2}$ partial pressure on $1 \mathrm{wt} \% \mathrm{~K}-0.25 \mathrm{wt} \% \mathrm{Pd}-\mathrm{Cu}_{0.5} \mathrm{Mg}_{5}$ $\mathrm{CeO}_{x}$ and $1 \mathrm{wt} \% \mathrm{~K}-\mathrm{Cu}_{0.5} \mathrm{Mg}_{5} \mathrm{CeO}_{x}\left(583 \mathrm{~K}, 4.5 \mathrm{MPa}, \mathrm{H}_{2} / \mathrm{CO}=1\right)$.

alcohol synthesis rates and selectivities. Table 3 shows $\mathrm{CO}$ conversion and product selectivities for $0.9 \mathrm{wt} \%$ $\mathrm{K}-\mathrm{Cu}_{7.5} \mathrm{Mg}_{5} \mathrm{CeO}_{x}$ and $1 \mathrm{wt} \% \mathrm{~K}-\mathrm{Cu}_{0.5} \mathrm{Mg}_{5} \mathrm{CeO}_{x}$.

At similar $\mathrm{CO}$ conversions, isobutanol synthesis rates are higher on the catalyst with high $\mathrm{Cu}$ content.
Isobutanol selectivity, however, is lower on this catalyst. Isobutanol selectivity does not increase with decreasing space velocity on the catalyst with high $\mathrm{Cu}$ content (in contrast with the low $\mathrm{Cu}$ content catalyst). This reflects stronger inhibition effects at the very high $\mathrm{CO}$ conversions obtained with decreasing space velocity on this catalyst.

The $0.9 \mathrm{wt} \% \quad \mathrm{~K}-\mathrm{Cu}_{7.5} \mathrm{Mg}_{5} \mathrm{CeO}_{x}$ catalyst has a higher selectivity to methyl acetate than the $1.0 \mathrm{wt} \% \mathrm{~K}-\mathrm{Cu}_{0.5} \mathrm{Mg}_{5} \mathrm{CeO}_{x}$ catalyst. Methyl acetate and other esters can be formed by Canizzaro-type condensations of two aldehydes, by reactions of surface carboxylates with formyl or formaldehyde, or by Tishchenko-type reactions of aldehyde species with surface alkoxides [3]. The latter reaction seems to be the most plausible pathway, in view of the expected presence of both aldehydes and surface alkoxides on our catalytic materials. The high selectivity to methyl acetate on the $0.9 \mathrm{wt} \% \mathrm{~K}-\mathrm{Cu}_{7.5} \mathrm{Mg}_{5} \mathrm{CeO}_{x}$ catalyst suggests that $\mathrm{Cu}$ sites promote the formation of methyl acetate, possibly by increasing aldehyde surface concentrations during higher alcohol synthesis.

Catalysts with high $\mathrm{Cu}$ concentrations show higher hydrocarbon selectivities than the catalysts with low $\mathrm{Cu}$ content at similar $\mathrm{CO}$ conversions. Hydrocarbons and dimethylether products require acid sites and hydrocarbon formation appears to require longer resi-

Table 3

Alcohol synthesis rates and selectivities on $0.9 \mathrm{wt} \% \mathrm{~K}-\mathrm{Cu}_{7.5} \mathrm{Mg}_{5} \mathrm{CeO}_{x}$ and $1 \mathrm{wt} \% \mathrm{~K}-\mathrm{Cu}_{0.5} \mathrm{Mg}_{5} \mathrm{CeO}_{x}(583 \mathrm{~K}, 4.5 \mathrm{MPa}, \mathrm{H} 2 / \mathrm{CO}=1)$

\begin{tabular}{|c|c|c|c|}
\hline \multirow{2}{*}{$\begin{array}{l}\text { Catalyst } \\
\text { Gas hourly space velocity } 9 \mathrm{~cm}^{3} / \mathrm{g} / \mathrm{h} \text { ) }\end{array}$} & \multicolumn{2}{|c|}{$0.9 \mathrm{wt} \% \mathrm{~K}-\mathrm{Cu}_{7.5} \mathrm{Mg}_{5} \mathrm{CeO}_{x}$} & \multirow{2}{*}{$\frac{1 \mathrm{wt} \% \mathrm{~K}-\mathrm{Cu}_{0.5} \mathrm{Mg}_{5} \mathrm{CeO}_{x}}{1500}$} \\
\hline & 6000 & 1500 & \\
\hline $\mathrm{CO}$ conversion $(\%)$ & 7.6 & 26.9 & 14.7 \\
\hline $\mathrm{CO}$ conversion rate (mmol CO conv./g/h) & 19.4 & 7.4 & 4.0 \\
\hline Methanol synthesis rate $(\mathrm{g} / \mathrm{kg} / \mathrm{h})$ & 289 & 58 & 65 \\
\hline Isobutanol synthesis rate $(\mathrm{g} / \mathrm{kg} / \mathrm{h})$ & 9.5 & 2.7 & 3.7 \\
\hline Methyl acetate synthesis rate $(\mathrm{g} / \mathrm{kg} / \mathrm{h})$ & 19.3 & 9.3 & 1.3 \\
\hline Methanol turnover rate $(\mathrm{mmol} / \mathrm{mol} \mathrm{Cu} / \mathrm{s})$ & 4.4 & 0.9 & 2.3 \\
\hline Isobutanol turnover rate $(\mathrm{mmol} / \mathrm{mol} \mathrm{Cu} / \mathrm{s})$ & 0.06 & 0.02 & 0.06 \\
\hline $\mathrm{CO}_{2}$ selectivity $(\% \mathrm{C})$ & 27.5 & 40.5 & 23.4 \\
\hline \multicolumn{4}{|l|}{ Carbon selectivities (\% $\mathrm{C} ; \mathrm{CO}_{2}$-free) } \\
\hline Methanol & 57.4 & 35.5 & 63.1 \\
\hline Isopropanol & 2.7 & 3.9 & 2.3 \\
\hline Ethanol & 2.0 & 1.2 & 1.8 \\
\hline 1-Propanol & 3.1 & 1.7 & 3.0 \\
\hline Isobutanol & 3.3 & 2.8 & 6.2 \\
\hline Paraffins & 19.9 & 39.0 & 9.9 \\
\hline Methyl acetate & 4.7 & 6.4 & 1.2 \\
\hline DME & 0.7 & 1.0 & 6.8 \\
\hline
\end{tabular}


dence and/or stronger acid sites than dimethylether. The high hydrocarbon selectivity on catalysts with high $\mathrm{Cu}$ concentrations reflects a higher acid density on these catalysts, possibly formed during the reduction of larger amounts of $\mathrm{CuO}$ than on catalysts with low $\mathrm{Cu}$ content. Hydrocarbon selectivity increases rapidly with decreasing space velocity on both catalysts, apparently because basic sites, but not acid sites, are inhibited by $\mathrm{CO}_{2}$.

Increasing $\mathrm{Cu}$ concentrations leads to catalysts that are more resistant to $\mathrm{CO}_{2}$ inhibition (Fig. 3). High $\mathrm{CO}_{2}$ concentrations titrate basic sites on both high and low $\mathrm{Cu}$ catalysts, but high $\mathrm{Cu}$ catalysts retain a higher density of $\mathrm{Cu}$ sites required for bifunctional condensation reactions leading to alcohol chain growth. Therefore, higher isobutanol synthesis rates are obtained on high $\mathrm{Cu}$ catalysts at similar levels of $\mathrm{CO}$ conversion and $\mathrm{CO}_{2}$ concentration.

\subsection{Effect of Cs concentration on the synthesis of higher alcohols}

The effect of increasing Cs concentration was studied on $\mathrm{Cu} / \mathrm{ZnO} / \mathrm{Al}_{2} \mathrm{O}_{3}$ catalysts. Methanol and higher alcohol synthesis rates were previously shown to reach a maximum with increasing alkali loading [3-5]. The amount required for optimum higher alcohol synthesis depends on the identity of the alkali added and on the density of acid sites that require titration on a given catalyst [22].

Table 4 shows alcohol synthesis rates on $\mathrm{Cu} / \mathrm{ZnO}$ / $\mathrm{Al}_{2} \mathrm{O}_{3}$ catalysts promoted with $\mathrm{Cs}$ at two concentration levels (1.2 and $2.9 \mathrm{wt} \% \mathrm{Cs}$ ). Data reported by Nunan et al. [22] on similar $\mathrm{Cs}-\mathrm{Cu} / \mathrm{ZnO} / \mathrm{Al}_{2} \mathrm{O}_{3}$ samples are also shown in Table 4. Increasing Cs concentrations from 1.2 to $2.9 \mathrm{wt} \%$ causes a significant increase in $\mathrm{C}_{2+}$-alcohol synthesis rates and a decrease in dimethylether synthesis rate. Dimethylether is formed by condensation of methanol on acid sites. Alkali promoters, such as Cs, appear to titrate acid sites and to increase the density of basic sites on these catalysts (Table 1). This leads to lower dimethylether selectivity and higher alcohol selectivity as increasing amounts of Cs are added. At very high Cs concentrations, alcohol synthesis rates may ultimately decrease, because $\mathrm{Cu}$-metal sites, required for chain growth, can also be titrated by Cs species.
Table 4

Higher alcohol synthesis on Cs-promoted $\mathrm{Cu} / \mathrm{ZnO} / \mathrm{Al}_{2} \mathrm{O}_{3}$ catalysts.

\begin{tabular}{llll}
\hline & Ref. [22] & This study & This study \\
\hline Cs (wt\%) & $4.3^{1}$ & 1.2 & 2.9 \\
Cu (wt\%) & 35 & 44 & 44 \\
Temperature (K) & 583 & 583 & 580 \\
Pressure (MPa) & 7.6 & 4.5 & 4.5 \\
$\mathrm{H}_{2} / \mathrm{CO}$ ratio & 0.45 & 1 & 1 \\
Gas hourly space velocity & 5330 & 6000 & 6000 \\
(cm $\left.{ }^{3} / \mathrm{g} / \mathrm{h}\right)$ & & & \\
CO conversion (\%) & - & 15.0 & 15.4 \\
Synthesis rate (g/kg/h) & & & \\
Methanol & 405.0 & 269.6 & 342.3 \\
Ethanol & 12.6 & 12.0 & 16.1 \\
1-Propanol & 6.1 & 6.4 & 21.9 \\
1-Butanol & 5.5 & 0.8 & 0.3 \\
2-Methyl-1-propanol & 9.4 & 8.1 & 20.3 \\
Methyl formate & 10.4 & 1.3 & 0.4 \\
Methyl acetate & 3.4 & 13.8 & 4.2 \\
Dimethylether & - & 21.3 & 5.7 \\
Hydrocarbons & 13.9 & 12.9 & 6.2 \\
\hline l &
\end{tabular}

${ }^{1}$ Calculated using data from Ref. [22].

Higher Cs concentrations also lead to lower methyl acetate formation rates, suggesting that $\mathrm{Cs}$ addition favors aldol condensation reactions over esterification reactions or that Cs promotes the conversion of acetate to ethanol, in contrast with earlier reports [5], which found that selectivities to esters and alcohols followed similar trends. Our results are consistent with the involvement of similar intermediates in esterification and aldol condensation steps; species such as adsorbed acetaldehyde are likely to participate both in methyl acetate formation and in 1-propanol formation. The decrease in methyl acetate synthesis rate and the increased isobutanol synthesis rate at high Cs concentrations suggest that Cs selectively promotes aldolcoupling reactions.

\subsection{Alcohol addition to $\mathrm{H}_{2}-\mathrm{CO}$ reactants}

Ethanol and 1-propanol were added to the $\mathrm{H}_{2} / \mathrm{CO}$ feed in order to probe chain growth pathways in higher alcohol synthesis. Isotopic tracer studies of ethanol reactions on $\mathrm{K}-\mathrm{Cu}_{0.5} \mathrm{Mg}_{5} \mathrm{CeO}_{x}$ catalysts $[33,34]$ have shown that ethanol self-condensation reactions produce $n$-butyraldehyde, acetone, methylethyl ketone and 2-pentanone, which form 1-butanol, isopropanol, 2-butanol and 2-pentanol, respectively, at conditions 
Table 5

Ethanol and 1-propanol addition on $2.9 \mathrm{wt} \% \mathrm{Cs}-\mathrm{Cu} / \mathrm{ZnO} / \mathrm{Al}_{2} \mathrm{O}_{3}$ $\left(583 \mathrm{~K}, 4.5 \mathrm{MPa}, 6000 \mathrm{~cm}^{3} / \mathrm{g}\right.$ cat $/ \mathrm{h}, \mathrm{H}_{2} / \mathrm{CO} / \mathrm{Ar} / \mathrm{C}_{2} \mathrm{H}_{5} \mathrm{OH}=44.5 /$ 44.5/0.1/0.02 and $\mathrm{H}_{2} / \mathrm{CO} / \mathrm{Ar} / \mathrm{C}_{3} \mathrm{H}_{7} \mathrm{OH}=44.5 / 44.5 / 0.1 / 0.01$ )

\begin{tabular}{lrrrrr}
\hline & None & \multicolumn{2}{c}{ Ethanol None } & Propanol & None \\
\hline CO conversion (\%) & 15.4 & 14.8 & 14.8 & 14.2 & 14.3 \\
Selectivities & & & & & \\
(CO ${ }_{2}$-free) (\% C) & & & & & \\
Methanol & 67.6 & 67.5 & 69.2 & 69.9 & 71.0 \\
Ethanol & 4.4 & 12.2 & 4.3 & 3.5 & 4.2 \\
1-Propanol & 6.9 & 21.6 & 7.2 & 24.3 & 7.0 \\
2-Propanol & 0.7 & 2.8 & 0.6 & 1.1 & 0.6 \\
2-Methyl-1-propanol & 6.9 & 14.8 & 6.3 & 28.6 & 5.9 \\
1-Butanol & 1.0 & 2.9 & 1.0 & 2.0 & 0.9 \\
1-Pentanol & 0.3 & 1.2 & 0.3 & 1.4 & 0.2 \\
1-Hexanol & 0.2 & 0.6 & 0.2 & 0.5 & 0.2 \\
2-Methyl-1-butanol & 1.2 & 2.3 & 1.1 & 1.4 & 1.0 \\
2-Methyl-1-pentanol & 0.9 & 1.6 & 0.8 & 1.5 & 0.8 \\
2-Methyl-1-hexanol & 0.5 & 0.8 & 0.4 & 0.5 & 0.4 \\
Methyl acetate & 1.1 & 1.6 & 1.0 & 0.6 & 0.7 \\
Dimethylether & 0.8 & 0.3 & 0.7 & 0.5 & 0.6 \\
\hline
\end{tabular}

typical of CO hydrogenation reactions. Isotopic tracer studies of methanol-acetaldehyde reactions have shown that propionaldehyde and 1-propanol are formed by condensation of methanol-derived $\mathrm{C}_{1}$ species with acetaldehyde; isobutyraldehyde and isobutanol are formed by a similar $\mathrm{C}_{1}$ addition to propionaldehyde [33,34].

Table 5 shows product selectivities on $2.9 \mathrm{wt} \%$ Cs$\mathrm{Cu} / \mathrm{ZnO} / \mathrm{Al}_{2} \mathrm{O}_{3}$ catalysts when ethanol was added to $\mathrm{H}_{2} / \mathrm{CO}$ reactants. The molar concentration of ethanol in the feed was about $25 \%$ of the methanol concentration in the reactor effluent. The selectivity to 1propanol increases when ethanol is added, as expected from its formation via $C_{1}$ addition to $C_{2}$ intermediates. 1-Propanol can be formed both by aldol coupling and by linear chain growth (carbonylation) pathways. The selectivity to isobutanol also increases when ethanol is added. Isobutanol is formed only by $\mathrm{C}_{1}$ addition to 1 propanol (or propionaldehyde). 1-Butanol selectivity also increased; 1-butanol can be formed by linear chain growth pathways or by ethanol aldol self-condensation pathways. Ethanol self-condensation can also lead to 2-propanol (after retro-aldol reactions) and 2-butanol. Increased selectivity for 2-propanol shows that self-condensation does occur, and that 1butanol is predominantly formed by ethanol aldol selfcondensation instead of linear chain growth pathways.
The selectivity to 1-pentanol and 1-hexanol also increases. 1-Pentanol can be formed by condensation of ethanol with propanol or by linear chain growth of 1-butanol. 1-Hexanol is formed by condensation of ethanol with 1-butanol or by linear chain growth of 1-pentanol.

Table 5 shows the effect of adding 1-propanol to the $\mathrm{H}_{2} / \mathrm{CO}$ feed. The molar concentration of 1-propanol in the feed was $20 \%$ of the methanol concentration in the reactor effluent. The large increase in isobutanol selectivity during 1-propanol addition confirms that isobutanol is formed predominantly by aldol-type $\mathrm{C}_{1}$ addition to $\mathrm{C}_{3}$ species derived from 1-propanol. The slight increase in 1-butanol selectivity during 1-propanol addition shows that minority linear chain growth pathways are available on $\mathrm{Cs}-\mathrm{Cu} / \mathrm{ZnO} / \mathrm{Al}_{2} \mathrm{O}_{3}$. The ratio of the increase in isobutanol selectivity to the increase in 1-butanol selectivity when propanol is added shows that aldol condensation pathways are ca. 22 times faster than linear chain growth steps on $2.9 \mathrm{wt} \% \mathrm{Cs}-\mathrm{Cu} / \mathrm{ZnO} / \mathrm{Al}_{2} \mathrm{O}_{3}$ at the conditions of our study.

Table 6 shows the effect of adding 1-propanol to the $\mathrm{H}_{2} / \mathrm{CO}$ feed on a $1.2 \mathrm{wt} \% \mathrm{~K}-\mathrm{Cu}_{7.5} \mathrm{Mg}_{5} \mathrm{CeO}_{x}$ catalyst. The ratio of the increase in isobutanol selectivity to the increase in 1-butanol selectivity on this catalyst is somewhat lower $(\sim 9)$ than for the $2.9 \mathrm{wt} \% \mathrm{Cs}-\mathrm{Cu} /$ $\mathrm{ZnO} / \mathrm{Al}_{2} \mathrm{O}_{3}$, but aldol-type $\mathrm{C}_{1}$ addition steps remain the predominant chain growth pathway on $\mathrm{K}$ $\mathrm{Cu}_{7.5} \mathrm{Mg}_{5} \mathrm{CeO}_{x}$ catalysts.

Table 6

1-Propanol addition on $1.2 \mathrm{wt} \% \mathrm{~K}-\mathrm{Cu}_{7.5} \mathrm{Mg}_{5} \mathrm{CeO}_{x}(583 \mathrm{~K}$, $4.5 \mathrm{MPa}, 1500 \mathrm{~cm}^{3} / \mathrm{g} \mathrm{cat} / \mathrm{h}, \mathrm{H}_{2} / \mathrm{CO} / \mathrm{Ar} / \mathrm{C}_{3} \mathrm{H}_{7} \mathrm{OH}=44.5 / 44.5 / 0.1 /$ $0.5)$

\begin{tabular}{lcc}
\hline & None & Propanol \\
\hline CO conversion $(\%)$ & 16.0 & 15.4 \\
Selectivities $\left(\mathrm{CO}_{2}\right.$-free) $(\%)$ & & \\
Methanol & 60.6 & 53.3 \\
Ethanol & 2.8 & 1.2 \\
1-Propanol & 4.3 & - \\
2-Propanol & 3.0 & 1.3 \\
2-Methyl-1-propanol & 4.1 & 15.5 \\
1-Butanol & 0.2 & 1.5 \\
1-Pentanol & 0.1 & 1.0 \\
1-Hexanol & 0.2 & 0.4 \\
2-Methyl-1-butanol & 0.5 & 1.3 \\
2-Methyl-1-pentanol & 0.2 & 1.3 \\
\hline
\end{tabular}


Aldol-type addition of $\mathrm{C}_{1}$ species to linear alcohols leads to 2-methyl alcohols. The increase in 2-methyl1-butanol and 2-methyl-1-pentanol is caused by the higher 1-butanol and 1-pentanol selectivity, respectively, when 1-propanol is added and also by the condensation of ethanol with propanol (leading to 2-methyl-1-butanol) and of two propanol molecules (leading to 2-methyl-1-pentanol). A reasonable estimate of the contribution of carbonylation reactions to chain growth can be obtained by assuming that all products that can form from 1-butanol (1-pentanol, 1hexanol, 2-methyl-1-butanol, 2-methyl-1-pentanol, etc.), are actually formed only from 1-butanol. Even then, aldol condensation pathways are about eight times faster than linear chain growth on $2.9 \mathrm{wt} \%$ $\mathrm{Cs}-\mathrm{Cu} / \mathrm{ZnO} / \mathrm{Al}_{2} \mathrm{O}_{3}$ catalysts.

Reaction pathways for the formation of observed products are shown in Fig. 5. These chain growth pathways are consistent with those proposed by Smith and Anderson [3], Smith et al. [23] and Breman et al. $[6,7]$ for modified methanol synthesis catalysts. This scheme suggests the possibility of applying chain growth analysis methods similar to those developed by Herrington [42] to examine chain growth kinetics for the Fischer-Tropsch synthesis. The analysis becomes more complex for higher alcohol synthesis because chain growth occurs via several parallel pathways.

In order to apply these methods, chain termination probabilities for each chain size, (n) are obtained using the expression:

$\beta_{n} \equiv r_{\mathrm{t}, n} / r_{\mathrm{p}, n}=\phi_{n} / \sum_{n=n+1}^{\infty} \phi_{i}$,

where $\phi_{n}$ is the mole fraction of chains of with $n$ carbon atoms in the reactor effluent and $r_{\mathrm{t}, n}$ and $r_{\mathrm{p}, n}$ are the termination and propagation rates, respectively, for such chains with $n$-carbon atoms. The total termination probability $\left(\beta_{\mathrm{T}, n}\right)$ then becomes a linear combination of the values for the individual termination steps for all pathways leading to gas phase species with $n$ carbon atoms:

$\beta_{\mathrm{T}, n}=\beta_{x, n}+\beta_{y, n}+\beta_{z, n}$,

where $\beta_{x, n}$ is the probability of termination via each distinct termination step, which can from the mole fraction of each species among reaction products using Eq. (7).
Both linear and aldol condensation chain growth by $\mathrm{C}_{1}$ can occur during higher alcohol synthesis. These pathways lead to different products, except for the growth step from $\mathrm{C}_{2}$ to $\mathrm{C}_{3}$, in which both carbonylation and aldol-type $\mathrm{C}_{1}$ addition lead to the same product (1-propanol). Self-condensation reactions of $\mathrm{C}_{2+}$ oxygenates, however, can also occur and they complicate the analysis.

As discussed above, linear chain growth is a minority pathway at the conditions of our study and it will be neglected in our chain growth analysis. Self-condensation of either ethanol or propanol, or ethanol with propanol, however, cannot be neglected. In our treatment, we will examine only the condensation steps described in Fig. 6. This analysis leads to the chain termination probabilities listed in Table 7 for $\mathrm{Cs}-\mathrm{Cu} / \mathrm{ZnO} / \mathrm{Al}_{2} \mathrm{O}_{3}$, when 1-butanol and 2-methyl-1pentanol are assumed to form only by self-condensation (of ethanol and propanol, respectively). 2-Methyl1-butanol and 1-pentanol are assumed to form by condensation of ethanol with propanol. The formation of non-primary alcohols (except for 2-propanol) is negligible and it was not included in this analysis.

All chain growth probabilities on $2.9 \mathrm{wt} \% \mathrm{Cs}-\mathrm{Cu} /$ $\mathrm{ZnO} / \mathrm{Al}_{2} \mathrm{O}_{3}$ increase with decreasing space velocity because longer bed-residence times and higher concentrations of intermediate products increases the probability for further chain growth reactions via readsorption and further chain growth of a $\mathrm{C}_{\mathrm{n}}$ alcohol. Higher Cs concentrations lead to higher alcohol chain growth probabilities.

Table 8 shows chain growth probabilities for several $\mathrm{Cu}_{\mathrm{y}} \mathrm{Mg}_{5} \mathrm{CeO}_{x}$ catalysts modified by $\mathrm{K}$ and $\mathrm{Pd}$

Table 7

Chain growth probabilities for $\mathrm{Cs}-\mathrm{Cu} / \mathrm{ZnO} / \mathrm{Al}_{2} \mathrm{O}_{3}(583 \mathrm{~K}, 4.5 \mathrm{MPa}$, $\mathrm{H}_{2} / \mathrm{CO}=1$ )

\begin{tabular}{llll}
\hline $\begin{array}{l}\text { Total chain growth } \\
\text { probability }\end{array}$ & $\begin{array}{l}1.2 \mathrm{wt} \% \mathrm{Cs}-\mathrm{Cu} / \\
\mathrm{ZnO} / \mathrm{Al}_{2} \mathrm{O}_{3}\end{array}$ & $\begin{array}{l}2.9 \mathrm{wt} \% \mathrm{Cs}-\mathrm{Cu} / \\
\mathrm{ZnO} / \mathrm{Al}_{2} \mathrm{O}_{3}\end{array}$ \\
\hline $\begin{array}{l}\text { Gas hourly space velocity } \\
\left(\mathrm{cm}^{3} / \mathrm{g} \text { cat./h] }\right.\end{array}$ & 6000 & 6000 & 1500 \\
\hline $\mathrm{CO}$ conversion $(\%)$ & 15.0 & 15.4 & 23.6 \\
\hline $\mathrm{C}_{1}$ (to $\left.\mathrm{C}_{2}\right)$ & 0.05 & 0.10 & 0.17 \\
$\mathrm{C}_{2}$ (to $\left.\mathrm{C}_{3}\right)$ & 0.25 & 0.55 & 0.66 \\
$\mathrm{C}_{3}$ (to $\left.i-\mathrm{C}_{4}\right)$ & 0.23 & 0.38 & 0.56 \\
$i-\mathrm{C}_{4}$ (to neo- $\left.\mathrm{C}_{5}\right)^{\mathrm{a}}$ & 0 & 0 & 0 \\
\hline
\end{tabular}

${ }^{\text {a }}$ Neo-pentanol (2,2-dimethyl-1-propanol) not detected. 


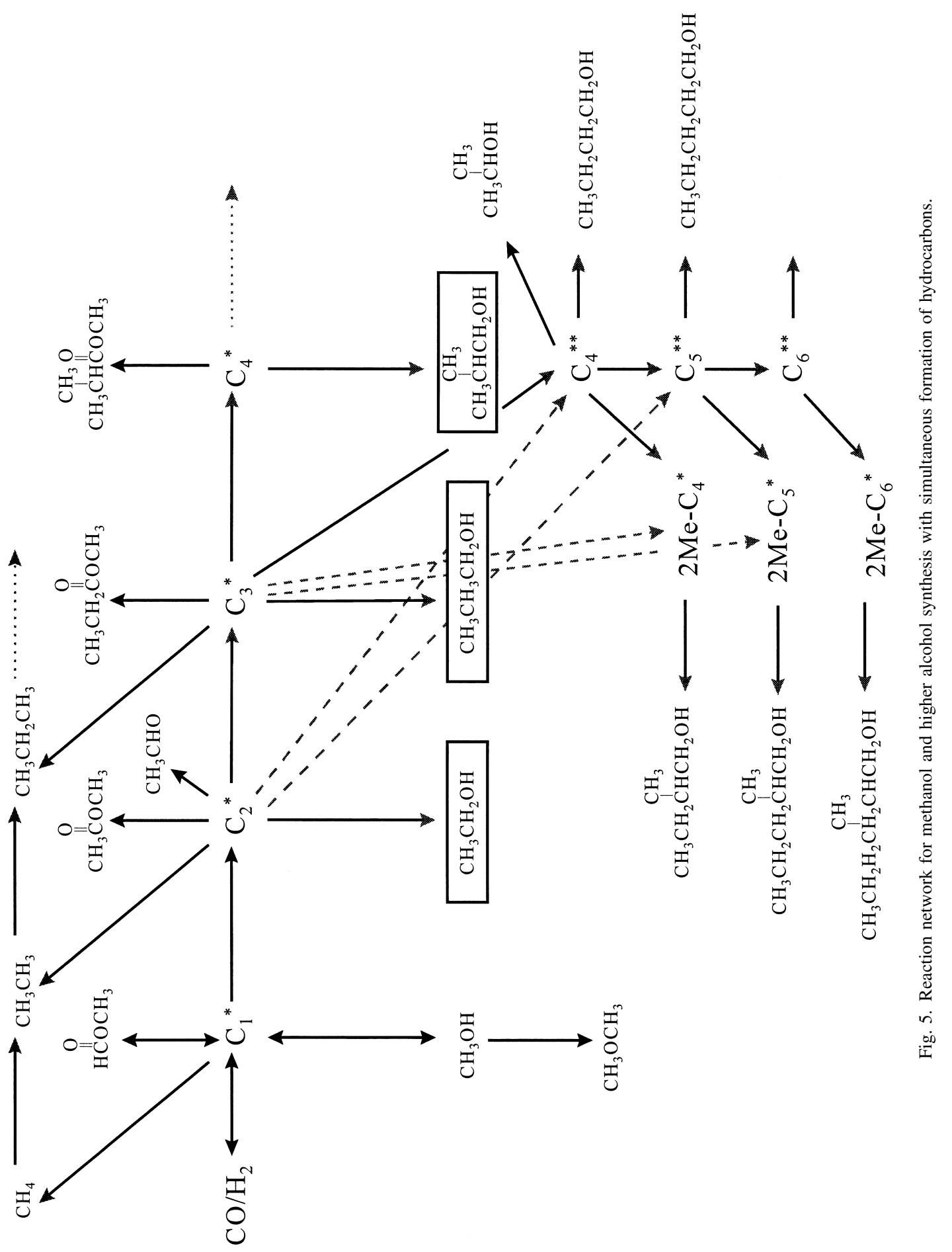




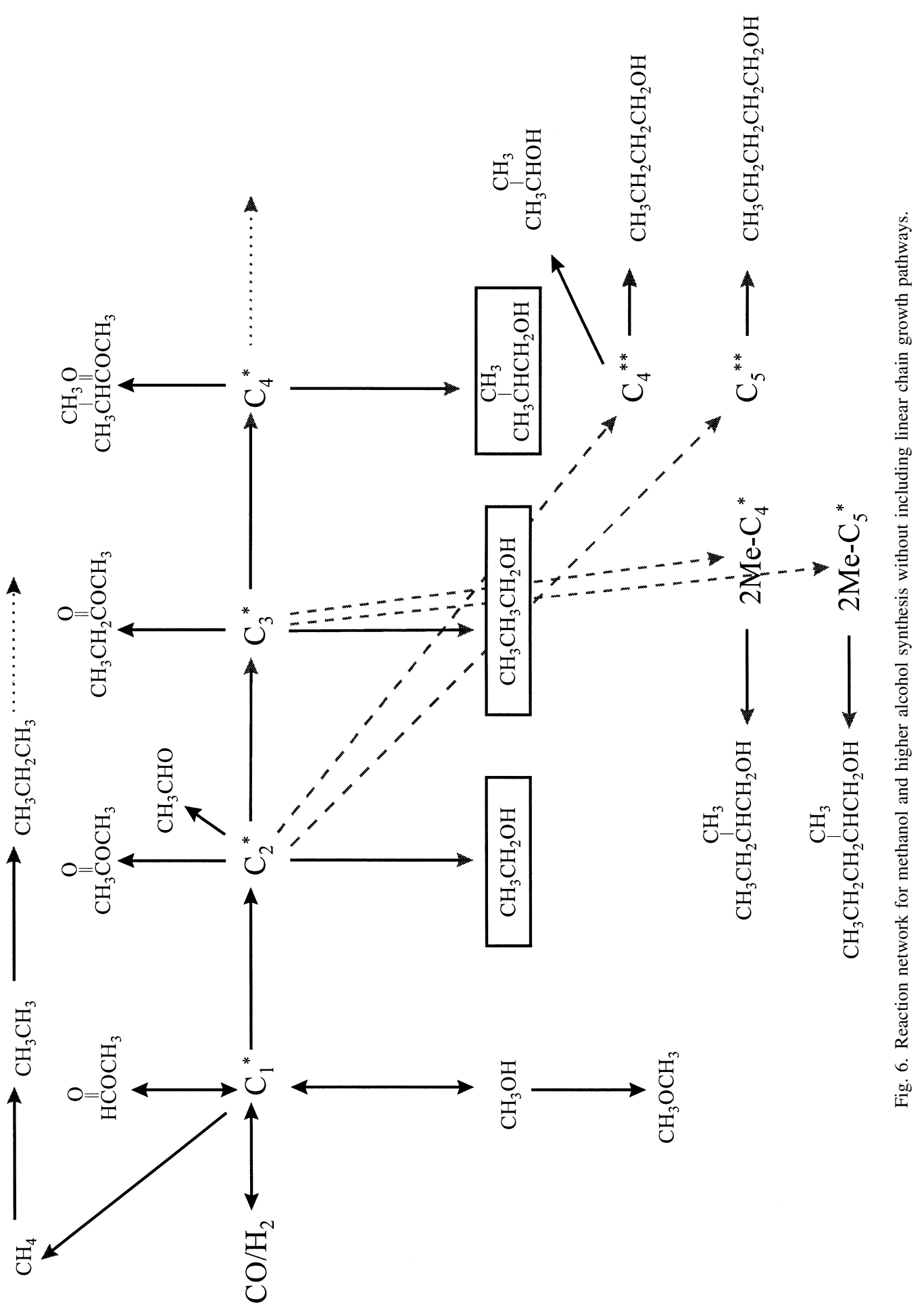


Table 8

Chain growth probabilities for $\mathrm{K}-\mathrm{Cu}_{0.5} \mathrm{Mg}_{5} \mathrm{CeO}_{x}$ and $\mathrm{Cs}-\mathrm{Cu} / \mathrm{ZnO} / \mathrm{Al}_{2} \mathrm{O}_{3}\left(583 \mathrm{~K}, 4.5 \mathrm{MPa}, \mathrm{H}_{2} / \mathrm{CO}=1\right)$

\begin{tabular}{|c|c|c|c|c|}
\hline $\begin{array}{l}\text { Total chain growth } \\
\text { probability }\end{array}$ & $\begin{array}{l}1 \mathrm{wt} \% \\
\mathrm{~K}-\mathrm{Cu}_{0.5} \mathrm{Mg}_{5} \mathrm{CeO}_{x}\end{array}$ & $\begin{array}{l}0.25 \mathrm{wt} \% \mathrm{Pd} 1 \mathrm{wt} \% \\
\mathrm{~K}-\mathrm{Cu}_{0.5} \mathrm{Mg}_{5} \mathrm{CeO}_{x}\end{array}$ & $\begin{array}{l}1 \mathrm{wt} \% \\
\mathrm{~K}-\mathrm{Cu}_{7.5} \mathrm{Mg}_{5} \mathrm{CeO}_{x}\end{array}$ & $\begin{array}{l}2.9 \mathrm{wt} \% \\
\mathrm{Cs}-\mathrm{Cu} / \mathrm{ZnO} / \mathrm{Al}_{2} \mathrm{O}_{3}\end{array}$ \\
\hline Gas hourly space velocity $\left(\mathrm{cm}^{3} / \mathrm{g}\right.$ cat $\left./ \mathrm{h}\right)$ & 1500 & 1500 & 6000 & 6000 \\
\hline $\mathrm{CO}$ conversion $(\%)$ & 14.7 & 15.8 & 17.6 & 15.4 \\
\hline$\overline{C_{1}}$ (to $C_{2}$ ) & 0.07 & 0.09 & 0.08 & 0.10 \\
\hline $\mathrm{C}_{2}$ (to $\mathrm{C}_{3}$ ) & 0.47 & 0.53 & 0.35 & 0.55 \\
\hline $\mathrm{C}_{3}\left(\right.$ to $\left.i-\mathrm{C}_{4}\right)$ & 0.54 & 0.50 & 0.27 & 0.38 \\
\hline$i-\mathrm{C}_{4}\left(\text { to neo- } \mathrm{C}_{5}\right)^{\mathrm{a}}$ & 0 & 0 & 0 & 0 \\
\hline
\end{tabular}

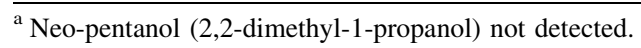

Table 9

Chain growth probabilities before, and during alcohol addition on $2.9 \mathrm{wt} \% \mathrm{Cs}-\mathrm{Cu} / \mathrm{ZnO} / \mathrm{Al}_{2} \mathrm{O}_{3}$. $\left(583 \mathrm{~K}, 4.5 \mathrm{MPa}, 6000 \mathrm{~cm}^{3} / \mathrm{g} \mathrm{cat} / \mathrm{h}\right.$, $\mathrm{H}_{2} / \mathrm{CO} / \mathrm{Ar} / \mathrm{C}_{2} \mathrm{H}_{5} \mathrm{OH}=44.5 / 44.5 / 0.1 / 0.02$, and $\mathrm{H}_{2} / \mathrm{CO} / \mathrm{Ar} / \mathrm{C}_{3} \mathrm{H} 7 \mathrm{OH}$ $=44.5 / 44.5 / 0.1 / 0.01$ )

\begin{tabular}{llll}
\hline Total chain growth probability & \multicolumn{3}{l}{ Molecule added to $\mathrm{H}_{2} / \mathrm{CO}$} \\
\cline { 2 - 4 } & none & ethanol & propanol \\
\hline $\mathrm{C}_{1}\left(\right.$ to $\left.\mathrm{C}_{2}\right)$ & 0.10 & - & - \\
$\mathrm{C}_{2}\left(\right.$ to $\left.\mathrm{C}_{3}\right)$ & 0.55 & 0.55 & - \\
$\mathrm{C}_{3}\left(\right.$ to $\left.i-\mathrm{C}_{4}\right)$ & 0.38 & 0.32 & 0.45 \\
\hline
\end{tabular}

compared at similar $\mathrm{CO}$ conversions. These catalysts show higher $\left(\mathrm{C}_{3}\right.$ to $\left.i \mathrm{C}_{4}\right)$ chain growth values than $\mathrm{Cs}-$ $\mathrm{Cu} / \mathrm{ZnO} / \mathrm{Al}_{2} \mathrm{O}_{3}$ catalysts, but chain growth values are otherwise very similar to those on $2.9 \mathrm{wt} \% \mathrm{Cs}-\mathrm{Cu} /$
$\mathrm{ZnO} / \mathrm{Al}_{2} \mathrm{O}_{3}$ for $\mathrm{C}_{1}$ and $\mathrm{C}_{2}$ species. $\mathrm{K}-\mathrm{Cu}_{7.5} \mathrm{Mg}_{5} \mathrm{CeO}_{x}$ shows lower chain growth values than similar catalysts containing lower $\mathrm{Cu}$ concentrations. This reflects a higher ratio of $\mathrm{Cu}$ to basic sites on these catalysts.

Table 9 shows chain growth probabilities when ethanol or propanol are added to the $\mathrm{H}_{2} / \mathrm{CO}$ feed. No significant changes in chain growth probabilities were detected when alcohols were added, as expected from their participation only in chain initiation steps.

\subsection{Comparison of $\mathrm{K}-\mathrm{Cu}_{y} \mathrm{Mg}_{5} \mathrm{CeO}_{x}$ and $\mathrm{Cu} / \mathrm{ZnO} /$ $\mathrm{Al}_{2} \mathrm{O}_{3}$ catalysts}

Table 10 shows selectivities and isobutanol synthesis rates for $1 \mathrm{wt} \% \mathrm{~K}-\mathrm{Cu}_{0.5} \mathrm{Mg}_{5} \mathrm{CeO}_{x}, 0.9 \mathrm{wt} \% \mathrm{~K}-$

Table 10

Comparison of $\mathrm{K}-\mathrm{Cu}_{y} \mathrm{Mg}_{5} \mathrm{CeO}_{x}$ and $\mathrm{Cs}-\mathrm{Cu} / \mathrm{ZnO} / \mathrm{Al}_{2} \mathrm{O}_{3}$ catalysts $\left(583 \mathrm{~K}, 4.5 . \mathrm{MPa}, \mathrm{H}_{2} / \mathrm{CO}=1\right.$ )

\begin{tabular}{|c|c|c|c|c|}
\hline Catalyst & $\begin{array}{l}1.0 \mathrm{wt} \% \\
\mathrm{~K}-\mathrm{Cu}_{0.5} \mathrm{Mg}_{5} \mathrm{CeO}_{x}\end{array}$ & $\begin{array}{l}0.9 \mathrm{wt} \% \\
\mathrm{~K}-\mathrm{Cu}_{7.5} \mathrm{Mg}_{5} \mathrm{CeO}_{x}\end{array}$ & $\begin{array}{l}1.2 \mathrm{wt} \% \\
\mathrm{Cs}-\mathrm{Cu} / \mathrm{ZnO} / \mathrm{Al}_{2} \mathrm{O}_{3}\end{array}$ & $\begin{array}{l}2.9 \mathrm{wt} \% \\
\mathrm{Cs}-\mathrm{Cu} / \mathrm{ZnO} / \mathrm{Al}_{2} \mathrm{O}_{3}\end{array}$ \\
\hline Gas hourly space velocity $\left(\mathrm{cm}^{3} / \mathrm{g}\right.$ cat. $\left.\mathrm{h}\right)$ & 1500 & 6000 & 6000 & 6000 \\
\hline $\mathrm{CO}$ conversion $(\%)$ & 14.7 & 17.6 & 15.0 & 15.4 \\
\hline Isobutanol rate $(\mathrm{g} / \mathrm{kg} / \mathrm{h})$ & 3.7 & 9.5 & 8.1 & 20.3 \\
\hline $\mathrm{CO}_{2}$ selectivity $(\% \mathrm{C})$ & 23.4 & 27.5 & 26.0 & 22.6 \\
\hline \multicolumn{5}{|l|}{ Carbon selectivities $\left(\% \mathrm{C} ; \mathrm{CO}_{2}\right.$ free $)$} \\
\hline Methanol & 63.1 & 57.4 & 63.5 & 67.6 \\
\hline Ethanol & 1.8 & 2.0 & 3.9 & 4.4 \\
\hline 1-Propanol & 3.0 & 3.1 & 2.3 & 6.9 \\
\hline 2-Methyl-1-propanol & 6.2 & 3.3 & 3.3 & 6.9 \\
\hline Methyl acetate & 1.2 & 4.7 & 2.8 & 1.1 \\
\hline Dimethylether & 6.8 & 0.7 & 7.0 & 0.8 \\
\hline Hydrocarbons & 4.7 & 19.9 & 5.5 & 2.5 \\
\hline Isobutanol/methanol molar ratio & 0.026 & 0.014 & 0.013 & 0.026 \\
\hline Surface $\mathrm{Cu}(\mathrm{mmol} / \mathrm{g})$ & 0.2175 & 0.5696 & n.d. & 0.3603 \\
\hline \multicolumn{5}{|l|}{ Turnover rates $\left(\mathrm{mmol} / \mathrm{mol} \mathrm{Cu} \mathrm{s}_{\mathrm{s}} / \mathrm{s}\right)$} \\
\hline Ethanol & 0.03 & 0.08 & - & 0.27 \\
\hline 1-Propanol & 0.04 & 0.08 & - & 0.28 \\
\hline Isobutanol & 0.06 & 0.06 & - & 0.21 \\
\hline
\end{tabular}


$\mathrm{Cu}_{7.5} \mathrm{Mg}_{5} \mathrm{CeO}_{x}, \quad 1.2 \mathrm{wt} \% \quad \mathrm{Cs}-\mathrm{Cu} / \mathrm{ZnO} / \mathrm{Al}_{2} \mathrm{O}_{3}$, and $2.9 \mathrm{wt} \% \mathrm{Cs}-\mathrm{Cu} / \mathrm{ZnO} / \mathrm{Al}_{2} \mathrm{O}_{3}$ catalysts at similar conversions. The $2.9 \mathrm{wt} \% \mathrm{Cs}-\mathrm{Cu} / \mathrm{ZnO} / \mathrm{Al}_{2} \mathrm{O}_{3}$ catalyst showed the highest isobutanol synthesis rates at $\mathrm{CO}$ conversions of ca. $15 \%$. Even on this catalyst, the molar ratio of isobutanol to methanol is only 0.03 . Decreasing the space velocity increased this ratio to 0.1 (at $1500 \mathrm{~cm}^{3} / \mathrm{g} / \mathrm{h}$ ) because methanol synthesis rates decrease with increasing bed-residence time due to thermodynamic constraints. $\mathrm{K}-\mathrm{Cu}_{\mathrm{y}} \mathrm{Mg}_{5} \mathrm{CeO}_{x}$ catalysts produce less isobutanol than $\mathrm{Cs}-\mathrm{Cu} / \mathrm{ZnO} /$ $\mathrm{Al}_{2} \mathrm{O}_{3}$ as a result of strong $\mathrm{CO}_{2}$ inhibition on these catalysts at higher $\mathrm{CO}$ conversion, but isobutanol synthesis rates are similar to those on $2.9 \mathrm{wt} \%$ Cs$\mathrm{Cu} / \mathrm{ZnO} / \mathrm{Al}_{2} \mathrm{O}_{3}$ at the low $\mathrm{CO}_{2}$ concentrations characteristic of low $\mathrm{CO}$ conversions.

Turnover rates for ethanol, 1-propanol and isobutanol are also shown in Table 10. There appears to be no direct correlation between $\mathrm{Cu}$ surface area and alcohol synthesis rates. This is not surprising, because alcohol synthesis rates depend not only on $\mathrm{Cu}$ site density, but also on the density and strength of basic sites and on their interaction with $\mathrm{CO}_{2}$ during alcohol synthesis reactions.

\section{Conclusions}

$\mathrm{K}-\mathrm{Cu}_{y} \mathrm{Mg}_{5} \mathrm{CeO}_{x}$ and $\mathrm{Cs}-\mathrm{Cu} / \mathrm{ZnO} / \mathrm{Al}_{2} \mathrm{O}_{3}$ were used for $\mathrm{CO}$ hydrogenation reactions to form higher alcohols. K-promoted $\mathrm{Cu}_{0.5} \mathrm{Mg}_{5} \mathrm{CeO}_{x}$ catalysts are active catalysts for isobutanol synthesis from $\mathrm{CO} / \mathrm{H}_{2}$ mixtures and give products with high alcohol-to-hydrocarbon ratios at relatively low temperatures $(583 \mathrm{~K})$ and pressures (4.5 MPa). Cs-promoted $\mathrm{Cu} / \mathrm{ZnO} / \mathrm{Al}_{2} \mathrm{O}_{3}$ catalysts show higher isobutanol synthesis rates than $\mathrm{K}-\mathrm{Cu}_{\mathrm{y}} \mathrm{CeMg}_{5} \mathrm{O}_{x}$ catalysts at high conversion conditions, but synthesis rates become similar at low $\mathrm{CO}$ conversions. $\mathrm{CO}_{2}$ strongly inhibits methanol and isobutanol synthesis rates on catalysts with low $\mathrm{Cu}$ concentration $\left(\mathrm{K}-\mathrm{Cu}_{0.5} \mathrm{Mg}_{5} \mathrm{CeO}_{x}\right)$. Methanol synthesis rates were not affected by $\mathrm{CO}_{2}$ on catalysts with high $\mathrm{Cu}$ content $\left(\mathrm{K}-\mathrm{Cu}_{7.5} \mathrm{Mg}_{5} \mathrm{CeO}_{x}\right.$ and $\mathrm{Cs}-\mathrm{Cu} / \mathrm{ZnO} /$ $\mathrm{Al}_{2} \mathrm{O}_{3}$ ), because they typically operate at methanol synthesis equilibrium. Isobutanol synthesis was more severely inhibited by $\mathrm{CO}_{2}$ on $\mathrm{K}-\mathrm{Cu}_{7.5} \mathrm{Mg}_{5} \mathrm{CeO}_{x}$ than on $\mathrm{Cs}-\mathrm{Cu} / \mathrm{ZnO} / \mathrm{Al}_{2} \mathrm{O}_{3}$, apparently as a result of the presence of stronger basic sites on the former. The addition of small amounts of $\mathrm{Pd}$ to $\mathrm{K}-\mathrm{Cu}_{0.5} \mathrm{Mg}_{5} \mathrm{CeO}_{x}$ weakens the adverse effects of $\mathrm{CO}_{2}$, probably because $\mathrm{Pd}$ resists oxidation and retains its hydrogenation activity at high $\mathrm{CO}_{2}$ partial pressures. The addition of $\mathrm{K}$ (or $\mathrm{Cs}$ ) to $\mathrm{Cu}_{\mathrm{y}} \mathrm{Mg}_{5} \mathrm{CeO}_{x}$ (or $\mathrm{Cu} / \mathrm{ZnO} / \mathrm{Al}_{2} \mathrm{O}_{3}$ ) samples titrates residual acid sites, which lead to dimethylether and hydrocarbons. Ethanol and 1-propanol addition data show that predominant chain growth pathways are aldol-type $\mathrm{C}_{1}$ addition to $\mathrm{C}_{2+}$ alcohols on both $\mathrm{K}-\mathrm{Cu}_{y} \mathrm{Mg}_{5} \mathrm{CeO}_{x}$ and $\mathrm{Cs}-\mathrm{Cu} / \mathrm{ZnO} /$ $\mathrm{Al}_{2} \mathrm{O}_{3}$. A chain growth analysis showed only minor differences in chain growth probabilities between the two types of catalysts examined in this study. This analysis also confirmed the role of alcohols as chain initiators during higher alcohol synthesis.

\section{Acknowledgements}

This work was supported by the Division of Fossil Energy of the United States Department of Energy under Contract Number DE-AC22-94PC94066. A.-M. Hilmen acknowledges the Norwegian Research Council for a post-doctoral fellowship. M.J.L. Gines acknowledges the Universidad Nacional del Litoral, Santa Fe, Argentina for a post-doctoral fellowship. The authors also express their thanks to Drs. Bernard Toseland and Richard Underwood of Air Products and Chemicals, Inc. for helpful suggestions and technical discussions.

\section{References}

[1] P. Forzatti, E. Tronconi, I. Pasquon, Cat. Rev. Sci. Eng. 33(1)\&2 (1991) 109.

[2] G. Natta, U. Colombo, I. Pasquon, in P.H. Emmet (Ed.), Catalysis, vol. V, Chap. 3, Reinhold, New York, 1957, p. 131.

[3] K.J. Smith, R.B. Anderson, Can. J. Chem. Eng. 61 (1983) 40.

[4] G.A. Vedage, P.B. Himelfarb, G.W. Simmons, K. Klier, ACS Symp. Ser. 279 (1985) 295.

[5] J.G. Nunan, C.E. Bogdan, K. Klier, K.J. Smith, C.-W. Young, R.G. Herman, J. Catal. 116 (1989) 195.

[6] B.B. Breman, A.C.C.M. Beenackers, E. Oesterholt, Chem. Eng. Sci. 49 (1994) 4409.

[7] B.B. Breman, A.C.C.M. Beenackers, E. Oesterholt, Catal. Today 24 (1995) 5.

[8] E.M. Calverley, R.B. Anderson, J. Catal. 104 (1987) 434.

[9] E.M. Calverley, K.J. Smith, J. Catal. 130 (1991) 616. 
[10] E.M. Calverley, K.J. Smith, Ind. Eng. Chem. Res. 31 (1992) 792.

[11] D.J. Elliott, F. Pennella, J. Catal. 114 (1988) 90.

[12] D.J. Elliott, F. Pennella, J. Catal. 119 (1989) 359.

[13] D.J. Elliott, J. Catal. 111 (1988) 445.

[14] A. Kiennemann, H. Idriss, R. Keiffer, P. Chaumette, D. Durand, Ind. Eng. Chem. Res. 30 (1991) 1130.

[15] J.C. Slaa, J.G. van Ommen, J.R.H. Ross, Catal. Today 15 (1992) 129.

[16] K.J. Smith, R.B. Anderson, J. Catal. 85 (1984) 428.

[17] K. Klier, V. Chatikavanij, R.G. Herman, G.W. Simmons, J. Catal. 74 (1982) 343.

[18] J.G. Nunan, K. Klier, C.-W. Young, P.B. Himelfarb, R.G. Herman, J. Chem. Soc. Chem. Commun. 193 (1986).

[19] K. Klier, R.G. Herman, J.G. Nunan, K.J. Smith, C.E. Bogdan, C.-W. Young, J.G. Santiesteban, in D.M. Bibby, C.D. Chang, R.F. Howe, S. Yurchak (Eds.), Methane Conversion, Elsevier, Amsterdam, vil. 188, 1988, p. 109.

[20] J.G. Nunan, C.E. Bogdan, K. Klier, K.J. Smith, C.-W. Young, R.G. Herman, J. Catal. 113 (1988) 410.

[21] J.G. Nunan, C.E. Bogdan, R.G. Herman, K. Klier, Catal. Lett. 2 (1989) 49.

[22] J.G. Nunan, R.G. Herman, K. Klier, J. Catal. 116 (1989) 222.

[23] K.J. Smith, C.-W. Young, R.G. Herman, K. Klier, Ind. Eng. Chem. Res. 30 (1991) 61.

[24] J.M. Campos-Martín, J.L.G. Fierro, A. Guerrero-Ruiz, R.G. Herman, K. Klier, J. Catal. 163 (1996) 418.

[25] A. Beretta, Q. Sun, R.G. Herman, K. Klier, Ind. Eng. Chem. Res. 35 (1996) 1534.
[26] C.R. Apesteguia, S. Soled, S. Miseo, US Patent 5,387, 570 (1993), assigned to Exxon Research and Engineering Co.

[27] C.R. Apesteguia, B. De Rites, S. Miseo, S. Soled, Catal. Lett. 44 (1997) 1.

[28] W. Keim, W. Falter, Catal. Lett. 3 (1989) 59.

[29] E. Tronconi, P. Forzatti, I. Pasquon, J. Catal. 124 (1990) 376.

[30] J.L. Robbins, E. Iglesia, C.P. Kelkar, B. De Rites, Catal. Lett. 10 (1991) 1

[31] G.C. Chinchen, K.C. Waugh, D.A. Whan, Appl. Catal. 25 (1986) 101

[32] M. Xu, E. Iglesia, Catal. Lett., in press.

[33] M.J.L Gines, E. Iglesia, J. Catal., in press.

[34] M. Xu, M.J.L. Gines, A.M. Hilmen, B.L. Stephens, E. Iglesia, J. Catal. 171 (1997) 130.

[35] G.C. Chinchen, P.J. Denny, J.R. Jennings, M.S. Spencer, K.C. Waugh, Appl. Catal. 36 (1988) 1.

[36] J.-L. Li, T. Inui, Appl. Catal. 137 (1996) 105.

[37] E. Iglesia, M. Boudart, J. Catal. 81 (1983) 204.

[38] K. Narita, N. Takezawa, I. Toyoshima, React. Kinet. Catal. Lett. 19 (1982) 91.

[39] M. Xu, E. Iglesia, J. Phys. Chem. 102 (1998) 961.

[40] E. Tronconi, N. Ferlazzo, P. Forzatti, I. Pasquon, Ind. Eng. Chem. Res. 26 (1987) 2122.

[41] N.W. Hurst, S.J. Gentry, A. Jones, B. McNicol, Catal. Rev.Sci. Eng. 24(2) (1982) 233.

[42] E.F.G. Herrington, Chem. Ind. 102 (1946) 346. 